\title{
Game On!
}

\section{Understanding the Emerging Game Meat Value Chain in South Africa}

Melanie Sommerville, Lindokuhle Khumalo, Tariro Kamuti, Shirley Brooks 


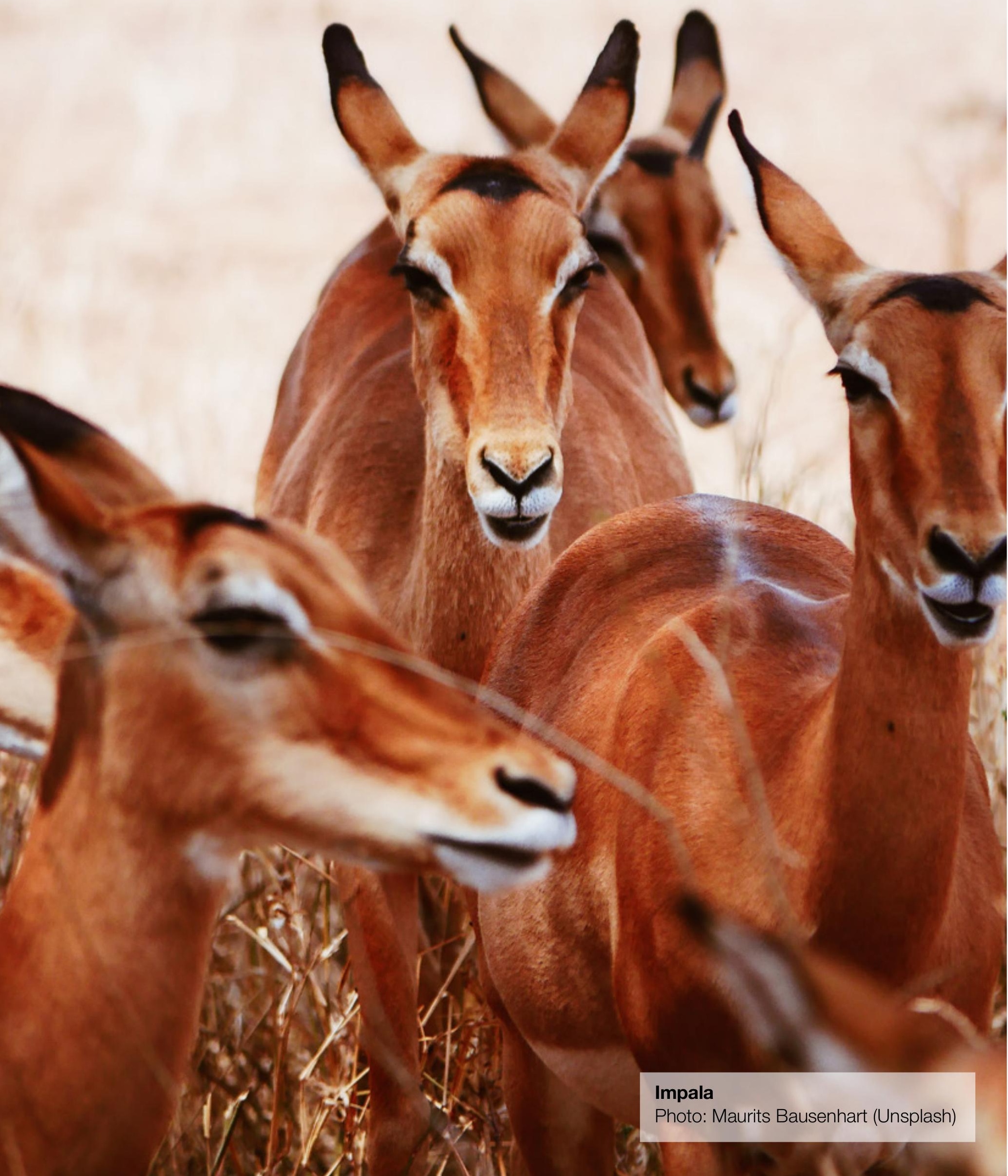




\section{Contents}

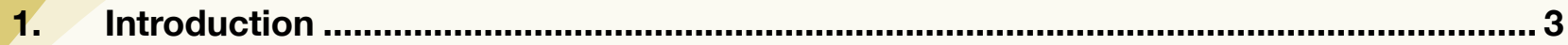

2. Game Production in South Africa and Beyond ..................................................... 5

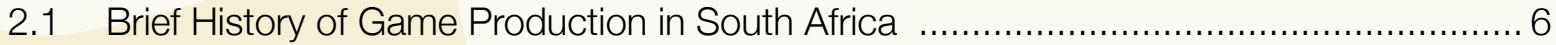

2.2 Extent and Scope of Contemporary Game Operations .......................................... 6

2.3 Economic Activity on Game Farms ........................................................... 8

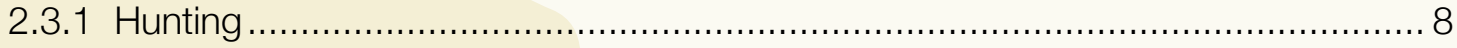

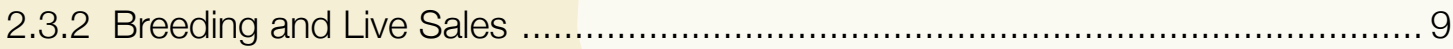

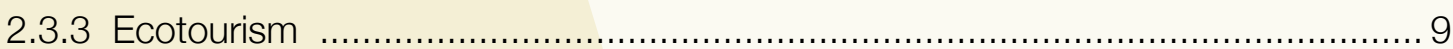

2.3.4 Processed Wildlife Products ................................................................. 11

2.4 Towards the 'Biodiversity Economy'? ............................................................. 11

2.5 Game Production Outside of South Africa .............................................................. 12

3. Growth and Change in the Game Sector: Contextualizing the Game Meat Value Chain.....15

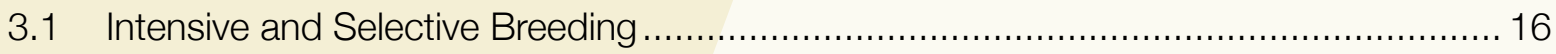

3.2 Accelerating Conversions and New Investors ................................................ 17

3.3 Changing Hunting Norms and Practices ...................................................... 18

3.4 Emergence of Community Game Farms........................................................ 19

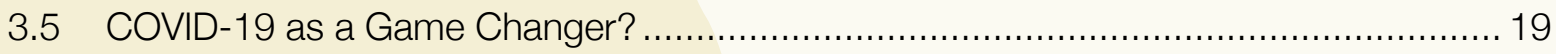

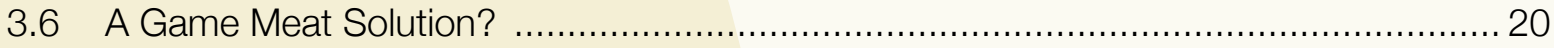

4. The Regulatory Framework for Game Meat Production ......................................... 23

4.1 Overlapping Mandates and Capacity Limitations .................................................... 24 
4.2 Game Meat Safety as a Regulatory Gap .................................................................. 25

4.3 Private Standards and Industry Certification Schemes ....................................... 26

5. Game Meat Value Chain Challenges................................................................................29

5.1 Socioeconomic and Transformation Challenges in the Game Meat Value Chain .......... 29

5.2 Environmental Sustainability and the Game Meat Value Chain ................................... 31

5.3 Health and Welfare Concerns Related to the Game Meat Value Chain ....................... 33

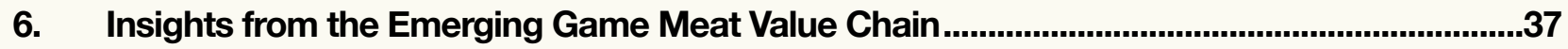

6.1 Advice for Front-Line Persons and Policy Makers ............................................ 38

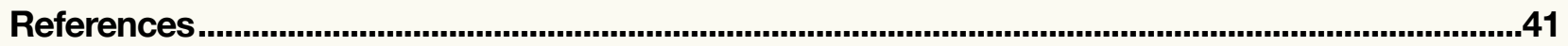

\section{List of Tables}

Table 1: Frequency of Economic Activities on South African Game Farms ............................... 8

Table 2: Estimated Animal Offtakes and Value of Meat Extracted from South African

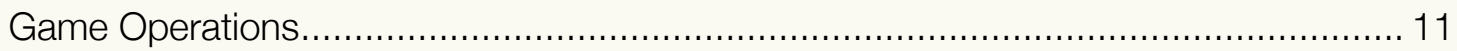

Table 3: Selective Summary of Diseases Affecting Game in South Africa................................... 36

\section{List of Figures}

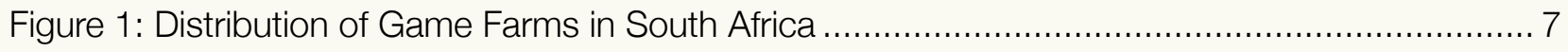

Figure 2: : Implementing the National Biodiversity Economy Strategy .................................... 13 


\section{Acknowledgements}

The authors would like to thank the following organizations, whose representatives participated in interviews and/or provided written comments used during our research:

- Republic of South Africa Department of Forestry, Fisheries and the Environment

- South African Hunters and Game Conservation Association

- African Game Ranchers Association

- South African Black Hunters and Sport Shooting Association

- Ezemvelo KZN Wildlife

- Conservation Outcomes

- Endangered Wildlife Trust

- Alsson (Pty) Ltd.

- African Leadership University School of Wildlife Conservation

Although we had several conversations with Wildlife Ranching South Africa about our research, they did not confirm their interest in participating in the project.

Hayley Abrahams, Jacob Cloete, and Musfiqah Majiet assisted with interview transcription.

Layout and graphics by Jess Nicholson (http://www.jessnicholson.com/).

The preparation of this Guidance Memo was funded by the Tiny Beam Fund, Inc.

(https://tinybeamfund.org/).

\section{About the Authors}

Melanie Sommerville is a Tenure Track Postdoctoral Fellow in the Department of International Environment and Development Studies (Noragric) at the Norwegian University of Life Sciences (NMBU), Norway.

Lindokuhle Khumalo is a PhD candidate in the Department of Social Anthropology at the University of Oslo, Norway.

Tariro Kamuti is a Research Fellow with the Global Risk Governance Programme in the Department of Public Law at the University of Cape Town, South Africa.

Shirley Brooks is an Associate Professor in the Department of Geography, Environmental Studies and Tourism at the University of the Western Cape, South Africa. 


\section{Introduction}

The production of wild game is big business in South Africa. Private game farming (also called wildlife ranching) has expanded steadily over the last thirty years, resulting in a rapid increase in wildlife populations. Despite recent instability in game prices, sector participants anticipate continuing growth in the coming decades.

South Africa's game farming industry is currently in flux. Some game farmers are employing increasingly sophisticated breeding technologies and pursuing more intensive models of game production. International, institutional, and individual investors are racing to capitalize on game-related projects, drawn by the promise of joining economic returns to biodiversity conservation through the newly termed 'biodiversity economy.' Intense debates are underway around the appropriateness of certain hunting activities. Marginalized rural communities that are part of South Africa's black majority are entering into the game sector through national land reform programs and biodiversity stewardship initiatives. Government departments, civil society organizations, and game sector representatives alike are asserting that while the COVID-19 pandemic delivered a significant blow to the game industry, wildlife production in South Africa is far from 'game over.'

This guidance memo examines contemporary efforts to formalize and expand the game meat value chain in South Africa's wildlife sector in the midst of this larger set of changes. ${ }^{1}$ Those in favour of an expanded value chain argue that game meat production will build more resilience into the sector

1 Our funder, the USA-based Tiny Beam Fund, notes that: "The main task of a fellowship recipient during the award period is to prepare one 6000-7000 wor[d] report which we call [a] Guidance Memo...Guidance Memos should provide sound information and clear explanations that deepen readers' understanding of the issues addressed, highlight key considerations that they may not be aware of, [and] offer practical advice that helps their work and decision-making." See: https://tinybeamfund.org/burning-questions-initiative/fellowship-awards/ 
economically and support inclusive socioeconomic development in South Africa's countryside. They suggest that the country's capacity to export game meats could quickly outpace other leading venison-producing nations globally. Relative to conventional livestock systems, game meat production may justifiably be promoted as being more environmentally sustainable and sensitive to animal welfare and human health concerns. Moreover, proponents of an upscaled value chain anticipate that game meat products will find eager consumers in both domestic and international markets, given the growing interest in 'wild,' and 'natural' food products.

Drawing on the expertise of people working on the frontlines of the wildlife sector, ${ }^{2}$ and written with policy makers in the areas of agriculture, conservation, ecotourism and rural development in mind, this guidance memo has five objectives:

- First, we provide a brief history of game production in South Africa and outline the extent, scope, and economic components of game operations today.

- Second, we examine the factors that we believe are driving the recent expansion, and in some cases intensification, of game farming, and in the process boosting efforts to formalize and expand game meat production and processing in South Africa.

- Third, we investigate the current regulatory framework for game meat production.

- Fourth, we reflect briefly on potential concerns related to socioeconomic development and transformation, environmental sustainability, and human health and animal welfare.

- And fifth, we provide recommendations that we hope will help ensure that these diverse concerns are considered alongside the economic benefits that participants hope to harness through game meat value chain formalization.

2 The short duration and limited funding associated with our project, together with challenges related to COVID-19 pandemic lockdowns, determined the nature and extent of interviews conducted for our research. Potential interviewees were identified according to their prominent roles or involvement in the wildlife sector. In-depth interviews were conducted via Zoom between January and April 2021. We also circulated a draft of this Guidance Memo to our participants, after which we made adjustments to incorporate their feedback or further clarify our perspective. Whilst we have made a sincere effort to obtain and reflect up-to-the-moment information, any errors of fact or interpretation are the responsibility of the authors and not our interview participants. In order to provide anonymity to our interviewees, we avoid identifying them by name, and only mention their organization when it is relevant to the point being made. 


\section{Game Production in South Africa and}

Beyond

Game production in South Africa today occurs on a variety of property types. This memo focuses on game operations on private and community lands, leaving aside South Africa's extensive system of national and provincial parks. We begin with a brief history of game production before describing the extent and scope of game operations today. We then examine the different economic components of game operations, before reviewing the status of game production in other countries globally. 


\subsection{Brief History of Game Production in South Africa}

In the period since South Africa's transition from apartheid to a democratic state in the early 1990s, the game industry has grown into a multi-billion Rand enterprise. ${ }^{3}$ Prior to this, domesticated animals (livestock) and undomesticated animals (wildlife) were clearly differentiated in law, with hunting privileges for the latter awarded by the state. Starting in the 1960s, some provincial conservation agencies encouraged farmers to keep wildlife on their land and supplied game animals to interested farmers. But in 1991, in the midst of the transition period and three years before the first democratic election, the national parliament passed the Game Theft Act, laying the foundation for the effective privatization of wildlife. $^{4}$

Prior to the 1991 Act, wild animals in South Africa were res nullius, meaning that they had no formal owner. ${ }^{5}$ The Act changed this, making it legal for farmers to own wildlife on their properties provided they erected suitable fencing. Investment in wild game now made economic sense as well as (it was argued) conservation sense. It was now possible for a farmer to buy wild animals at auction, to allow them to reproduce or breed them, and to offer them for hunting on their farm properties.

The Act created a new - and largely unregulated - game industry. At the same time, the end of the apartheid era saw international tourists return to South Africa following years of formal and informal economic sanctions. This presented new opportunities to market the viewing or hunting of the country's rich wildlife to wealthy visitors.

The key driver of expanded wildlife production in South Africa was farmers who converted conventional cattle- or other farms to game farms and private game reserves. ${ }^{6}$ Academic research has identified several underlying reasons for this trend, including the discontinuation of state farming subsidies, high levels of livestock theft, farmers' fear of losing their farms to the national land reform initiative, and environmental deterioration of the underlying land base. ${ }^{7}$ Many farmers calculated that their economic future would be more secure in wildlife production.

Nearly thirty years into the post-apartheid era, wildlife farming in South Africa continues to expand according to a similar economic rationale, best captured in the oft-repeated phrase, 'if it pays, it stays. ${ }^{8}$ Game production has grown particularly rapidly in the last 15 years, making it an increasingly significant land use in rural areas.

\subsection{Extent and Scope of Contemporary Game Operations}

One of the major challenges for understanding game production in South Africa concerns the scarcity of data on the industry. Various surveys and industry figures suggest that there are between 9,000 and 11,000 game operations in the country, covering 17 to 20.5 million hectares. ${ }^{9}$ This area is equivalent to 14 to $17 \%$ of South Africa's land base. Nearly $50 \%$ of existing game farms are located in the province of Limpopo, with the others spread between South Africa's eight remaining provinces (Figure

3 On 1 April 2021, USD 1 = ZAR 14.63.

4 The legislative change was the result of an increasingly heated debate about the relationship between property ownership and wildlife ownership in South Africa. For an overview, see: Snijders (2015).

5 Muir-Leresche and Nelson (2000); Snijders (2012).

6 Such conversions were already occurring in the 1970s and 1980 s but increased exponentially in the early post-apartheid era.

Spierenburg and Brooks (2014).

8 See: Oberem (2016); Kamuti (2019).

9 NAMC (2006); Dry (2016); Taylor et al. (2016). 
1). Together, these farms are said to accommodate some 16 to 20 million animals. ${ }^{10}$ Part of the variation in assessed game farm numbers may result from definitional differences. ${ }^{11}$

In this memo, we are concerned with the topic of game meat, and its current and potential production on a wide range of properties. On many of these properties, game meat production exists or can exist in conjunction with other land uses, as described further below.

\section{Figure 1: Distribution of Game Farms in South Africa}

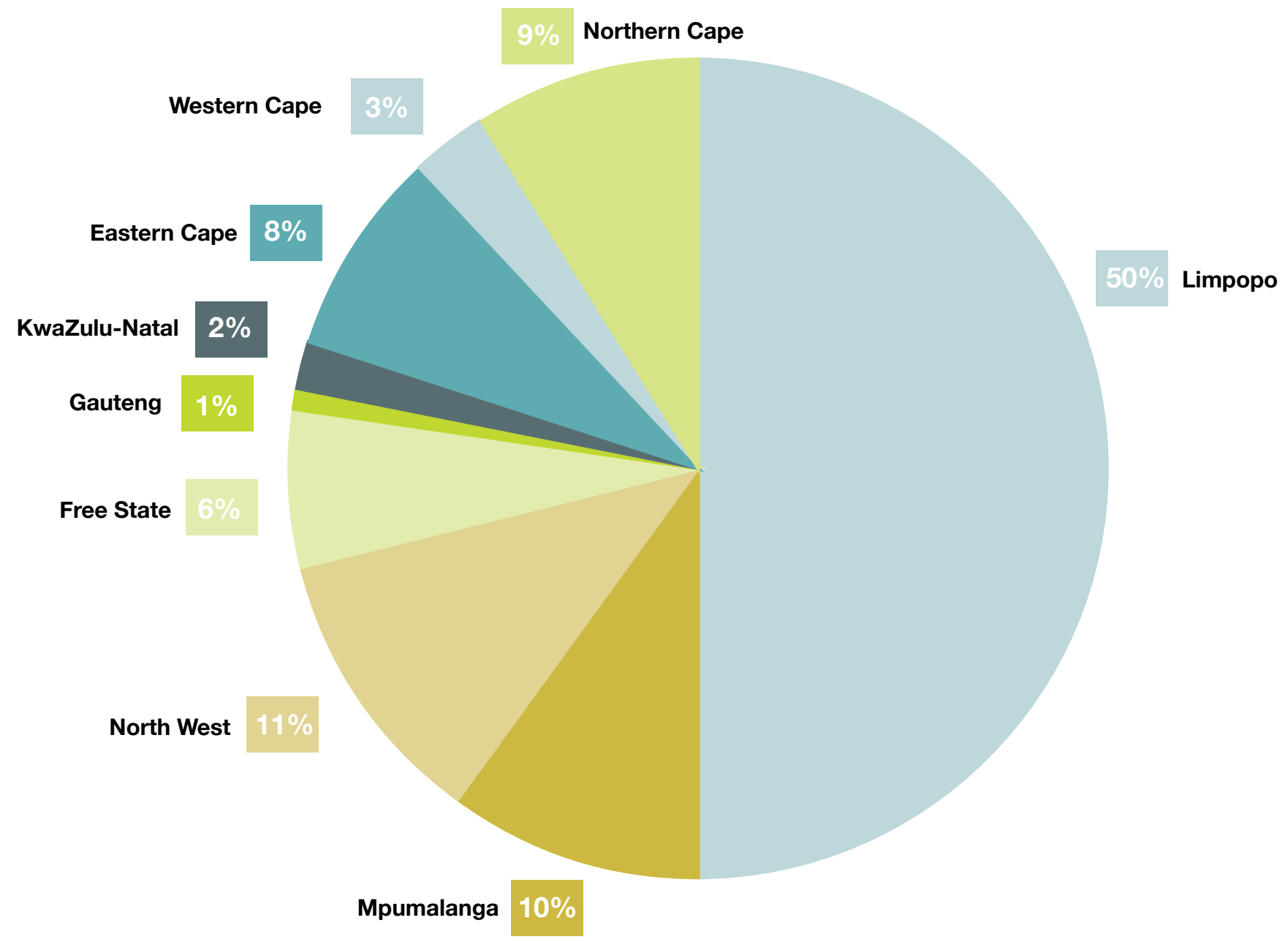

Data source: Taylor et al. (2016)

10 See: DEA (2016b); Dry (2016). Taylor et al. (2016) put the number at 6 million animals, although their count only includes herbivores.

11 While the terms are often used interchangeably, some industry participants draw subjective distinctions between 'game farms' (generally smaller properties, where game is managed more intensively), 'wildlife ranches' (larger and with less intensive management), and 'private game/nature reserves' (even larger and with still fewer management interventions). This may influence the percentages shown in Figure 1. 


\subsection{Economic Activity on Game Farms}

There are no definitive studies accounting for the full range of economic benefits derived from game production in South Africa. ${ }^{12}$ Following van der Merwe et al., game farming can be understood as resting on four distinct but overlapping economic pillars: hunting, breeding and live sales, ecotourism, and the sale of processed game products. ${ }^{13}$ Most farms engage in more than one of these activities (Table 1).

\section{Table 1: Frequency of Economic Activities on South African Game Farms}

\begin{tabular}{|l|c|}
\hline Activity & Percentage of Farms Engaging \\
\hline Hunting - trophy & $49 \%$ \\
\hline Hunting - biltong & $46 \%$ \\
\hline Hunting - both & $29 \%$ \\
\hline Intensive and selective breeding & $45 \%$ \\
\hline Live game sales & $63 \%$ \\
\hline Culling & $26 \%$ \\
\hline Ecotourism & $53 \%$ \\
\hline Combining wildlife production with livestock production & $46 \%$ \\
\hline
\end{tabular}

Data source: Taylor et al. (2016)

\subsubsection{Hunting}

South Africa's private game farms service both local hunters (sometimes called 'consumptive hunters' or colloquially 'biltong hunters', the latter with reference to a popular dried meat snack); and international hunters (often called 'safari' or 'trophy' hunters) (see Text Box). Hunting provides both direct and indirect revenues for game operators. Direct revenues include those derived from trophy prices, professional guiding, outfitting services, and other aspects of conducting hunts. Many game farms also feature lodges with accommodations and restaurants on their properties, providing the owner with income indirectly derived from the presence of wildlife.

Drawing on a range of earlier studies, van der Merwe calculates that biltong and trophy hunters together contributed ZAR 13.6 billion to the national economy in 2016/7. ${ }^{14}$

12 Wildlife Ranching South Africa (WRSA), one of the two major organizations representing game producers, regularly suggests that the sector contributes some ZAR 20 billion annually to the country's GDP and that it supports some 140,000 jobs (see for example Dry 2015). However, the organization does not provide a source for these figures, and it is unclear that they are based on independent or peer reviewed research. 13 van der Merwe et al. 2004.

14 Biltong hunters played a far larger economic role than trophy hunters, with about 200,000 frequent hunters spending approximately ZAR 58,000 per season for a total of almost ZAR 11.7 billion (van der Merwe 2018). The 7600 trophy hunters that visited South Africa in 2016, in turn, spent an average of ZAR 262,000 per trip, which once airfares are extracted results in a total economic stimulus of ZAR 2,525 million (Saayman et al. 2018). 


\section{'Biltong' vs 'Trophy' Hunting}

Biltong hunting has a long history in South Africa, going back to the period of colonization when hunting supported the livelihoods of settlers. Biltong hunters today are recreational hunters, often members of local hunting associations who enjoy hunting during the winter season and who consume the product of their hunts as venison. This form of hunting is sufficiently affordable that a reasonable number of people can still hunt annually.

Trophy hunting revolves, as the name implies, around securing animal trophies, often the horns or taxidermied head. The more impressive the animal, the higher its trophy price. Trophy hunting is very expensive and in South Africa is often undertaken by tourists from highly developed countries in the global North. Trophy hunters are required by law to use both a registered Professional Hunter and an outfitter on their hunts.

\subsubsection{Breeding and Live Sales}

Alongside hunting, many game farms also breed wildlife or provide stud services, with some specializing in this aspect. Wildlife breeding emerged gradually with the adoption of principles of 'scientific' game ranching and has come to play a larger role in the industry in recent decades. ${ }^{15}$ Wild animals popular with trophy hunters, in particular, are systematically bred to serve as stud animals.

Animals arising from such processes, as well as excess wildlife bred under extensive conditions, are offered as 'live sales' at game auctions or through private arrangements. Purchased animals are used to stock new game farms and reserves or to expand existing operations, for example to increase the range of species featured and/or to increase genetic diversity. ${ }^{16}$

At least until a recent decline in game prices, the breeding and live sales segment has played a key role in the economics of the game industry as a whole, with Cloete et al. suggesting that the segment contributes in excess of ZAR 10 billion to the economy nationally. ${ }^{17}$

\subsubsection{Ecotourism}

Alongside the use of wildlife for trophy and biltong hunting, many game ranches also support engagements with wildlife through South Africa's growing ecotourism sector. These include wildlife viewing or 'wildlife experiences' such as guided game drives. ${ }^{18}$ With wildlife being a key tourist attraction in South Africa, game farms serve as highly sought-after destinations.

Sector participants recognize that ecotourism offers tremendous economic value to both individual operators and the industry as a whole. An oft-repeated claim is that some $80 \%$ of international tourists visiting South Africa partake in some form of wildlife tourism. ${ }^{19}$

15 On the emergence of scientific game ranching, see Carruthers (2008).

16 Linked to this sale of game is the business of wildlife translocation, where animals are moved from the selling to the acquiring property, generally by road. Permitting for wildlife translocation is extremely complex and there are different regulations in different parts of the country. The costs of translocation have been climbing steadily alongside the trade in live animals.

17 Cloete et al. (2015) note that the value of game animals sold at formal auctions alone increased from ZAR 93 million in 2005 to more than ZAR 1.8 billion in 2014. Although private sales are more difficult to track, Taylor et al. (2016) estimate that they totalled more than ZAR 2.4 billion in the same year. Wildlife translocation, in turn, resulted in revenues totalling approximately ZAR 980.7 million (ibid.).

18 Many properties also offer various accommodation opportunities ranging from campsites to five-star luxury safari lodges. Among other nature-based activities that guests can enjoy are wildlife photography, birdwatching, fishing, hiking, quad bike or bicycle tours, and stargazing.

19 Given that tourism as a whole contributed almost ZAR 125 billion to South Africa's GDP in 2016 (StatsSA 2019), this points to a significant role for wildlife-based activities undertaken on game operations. 


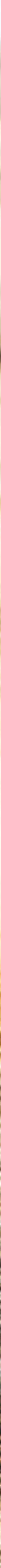




\subsubsection{Processed Wildlife Products}

The fourth economic pillar of the game industry comprises the production of processed wildlife products, including game meat, the focus of this memo. Some overlap exists between game meat production and hunting, whether for biltong or trophy purposes. ${ }^{20}$ Alongside hunting, game meat is also harvested by culling, either for commercial purposes or as part of regular management activities. ${ }^{21}$

Taylor et al. put animal offtakes from South African game operations at more than 584,000 animals in 2014 (Table 2). The value of the meat derived from animals removed by culling and trophy hunting surpassed ZAR 611 million. ${ }^{22}$

Alongside meat, there is a range of other processed products that can be produced from game animals. For example, animal skins and horn might be used in the production of rugs, furniture, and curios among other goods. One recent study suggests, however, that most game operators do not see these as commercial resources. ${ }^{23}$

\section{Table 2: Estimated Animal Offtakes and Value of Meat Extracted from South African Game Operations}

\begin{tabular}{|l|r|r|}
\hline Activity & Animal Offtake (number of animals) & Value of Meat (millions ZAR) \\
\hline Hunting - biltong & 277,027 & Not estimated \\
\hline Hunting - trophy & 130,186 & 262 \\
\hline Culling & 176,196 & 350 \\
\hline Total & 584,182 & 611 \\
\hline
\end{tabular}

Data source: Taylor et al. (2016)

\subsection{Towards the 'Biodiversity Economy'?}

Game farms in South Africa have been receiving increased public attention in recent years, with some aspects of their operations garnering intense debate. Participants and commentators in the sector often invoke the contributions made by game production to conservation and biodiversity in these discussions. ${ }^{24}$

20 With biltong hunting, the meat is the target of the hunt and is removed by the hunter for personal consumption. With trophy hunting, the meat is a by-product, and is generally retained by the property owner unless an arrangement exists with the outfitter or a local butchery or retailer.

21 Fencing turns game operations into closed ecological systems, necessitating a degree of 'ecological offtake' to keep species populations balanced and prevent overgrazing. Most operations engage professional culling operators who can remove the number of animals specified in management quotas quite efficiently (see https://www.pcoasa.co.za/). Less common are 'cull hunts' organized for interested clients.

22 Taylor et al. (2016) suggest that $61 \%$ of the resulting meat was sold domestically, $9 \%$ was used in guest accommodations on the properties, and $9 \%$ went to personal consumption. An additional 18\% was given as rations to farm workers on the properties in question, while $2 \%$ was sold to these workers.

23 Taylor et al. (2016).

24 Such framing responds to growing public and international concern about biodiversity loss, reflected for example in the Aichi Biodiversity Targets set by the Convention of Biological Diversity (CBD). 2020. Also relevant are longer-standing tensions between 'preservationist' and 'sustainable use' approaches to conservation, and their respective implications for game production and harvesting (for key arguments behind the two approaches, see Wilshusen et al. 2002; Hutton and Leader-Williams 2003). 
In 2015, South Africa's Department of Forestry, Fisheries and the Environment (DFFE) (then called the Department of Environmental Affairs) launched the National Biodiversity Economy Strategy (NBES), which aims to "enhance and create new and inclusive opportunities for economic growth through biodiversity based initiatives." The wildlife industry is one of two economic sub-sectors featured in the NBES, with DFFE asserting that the sector grew by 14\% per year between 2008 and 2013, contributing some ZAR 2.9 billion to the country's GDP by the end of that period. ${ }^{25}$

The NBES represents a key visioning document for the wildlife sector's future development. By tightly linking game operations to both economic opportunity and biodiversity conservation, the government appears to be targeting a more prominent role for game production in South Africa's economy going forward. The Department has identified a set of initiatives and recommendations to guide implementation of the strategy (see Figure 2). ${ }^{26}$ One of these initiatives focuses explicitly on game meat. In 2021, the Department began to develop a Game Meat Industry Strategy as a further pillar of the NBES.

Proponents of game meat and its centrality to the biodiversity economy outline a number of potential benefits associated with game meat production. These include the creation of jobs and economic value, the health benefits of the resulting product and its potential contributions to food security, and the environmental and animal welfare advantages of game production relative to conventional livestock production. While these points have substantial value, we nonetheless see a reason for advancing cautiously, given the particularly rapid growth of game farming in recent years and certain other trends in the wildlife sector. Before examining these topics in detail, we briefly discuss game production outside South Africa to help contextualize the remainder of our analysis.

\subsection{Game Production Outside of South Africa}

South Africa has so far been a minor player in the global game meat industry which is dominated by New Zealand and some European countries:

- New Zealand: As the world's largest and most advanced venison industry, New Zealand has an estimated one million red deer (Cervus elaphus) on its farms. ${ }^{27}$ National legislation classifies the country's farmed deer as 'wild animals in captivity,' and requires ranchers to hold permits for their operations. The industry exports between 12,000 and 15,000 tonnes of venison annually. ${ }^{28}$ Similar to South Africa, the animals have to be held behind a fence that meets an established standard.

- Spain: Producing 11,250 tonnes of venison annually, Spain is the second largest exporter of game meats. In that country deer are kept in game estates and the venison is almost entirely sourced from hunting. ${ }^{29}$

- Poland: Another important European venison producer is Poland, where deer farming obtained the status of a livestock and slaughter animal production industry in 2001. The number of farmed red deer grew from 900 to 9000 animals between 2004 and 2014, suggesting a growing interest in farming the species and potentially a growing market. ${ }^{30}$

25 DEA (2016a).

26 To a limited extent, one can track DFFE's progress on these initiatives and recommendations through DEA (2017); DEFF (2018); and DEFF (2020a,b).

27 Interestingly, deer are not native to New Zealand but were introduced from England and Scotland for hunting in the 19th century. Today however, $55 \%$ of Europe's demand for venison is covered by New Zealand's deer farms, since European production is yet to develop to a level where it can compete with the former (Kuba et al. 2015).

28 See https://www.deernz.org/about-deer-industry/nz-deer-industry/deer-industry-statistics/glance-industry-statistics\#.YPAcFaSoolQ.

29 Serrano et al. (2020)

30 Kuba et al. (2015) 


\section{Figure 2: Implementing the National Biodiversity Economy Strategy}

The Wildlife Economy Lab developed detailed plans for 15 initiatives and 6 additional recommendations

Facilitating
transformation

1. Identify and prioritise

$10 \mathrm{mHa}$ for transformation of wildlife economy

2. Coordinate existing support mechanisms under a 'Wild life Support Unit' to efficiently support new entrants to the industry

\section{Increase capacity} and support for at least 300 Community Entities including communal property agreements (CPAs), trusts and traditional authorities

\section{Create supply-chain linkages and capacitate 4000 small and medium- sized enterprises (new and existing) to locally capture the value of ancillary goods and services to the wildlife economy}

\section{Operationalise the uMfolozi Biodiversity Economy Node as a pilot for the wildlife node concept}

\section{Empower 4000 emerging entrepreneurs and farmers through focused capacity- building programmes}

i Develop a toolkit of effective wildlife business, stewardship and partnership models

\section{Driving growth through promoting 'value' and products}

7. Formalise South African game meat market and create a network of game meat processing facilities

8. Implement a campaign that drives participative transformation and consumer growth for wildlife-related activities and products

ii Promote sustainable use as a foundation for conservation and growth of biodiversity economy

iii Develop a strategic marketing campaign and value proposition for mixed game and livestock systems

iv Establish mechanisms to allow for holistic and integrated management of animal health and conflict issues at the livestockwildlife interface

v Fast track the development of norms and standards to actively manage and mitigate critical wildlife economy risks such as intensive and selective breeding, animal diseases and invasive species

Recommendations will be included with high level activities, but these will not have $3 \mathrm{ft}$ plans
Creating an enabling

environment for the wildlife sector

9. Create an enabling legislative environment through the amendment of the National Environmental Management: Biodiversity Act

10. Develop and implement wildlife industry standards

11. Implement a national wildlife economy branding scheme

12. Develop and implement an electronic wildlife permitting system and centralised database

13. 'Re-position' the Wildlife Forum as an efficient interdepartmental/ industry collaboration and co-ordination platform to promote the benefits of the Wildlife Economy

14. Develop an integrated knowledge/evidence generating and sharing platform to support the wildlife economy

\section{Leverage protected} areas to unlock economic potential

vi. Develop, upskill and resource extension services to facilitate the growth of the wildlife economy 


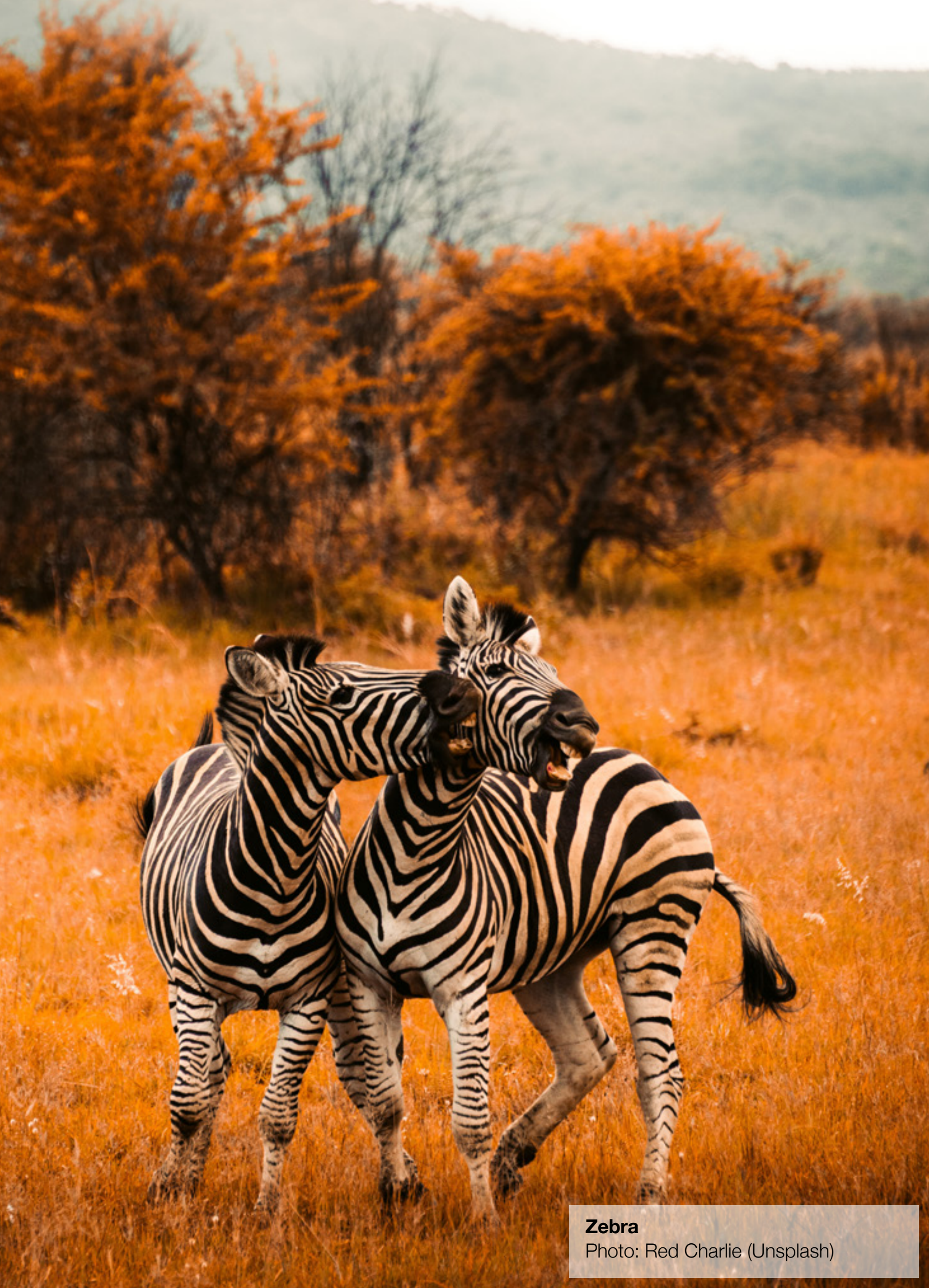




\section{Growth and Change in the Game Sector: Contextualizing the Game Meat Value Chain}

By the early 2000s, game production in South Africa was a still new but increasingly established industry, with animals produced mainly under extensive conditions on larger farms and reserves. But the last 15 years have seen both the expansion and, at some operations, the intensification of game production. These processes, which some suggest may now be resulting in an 'oversupply' of animals on some South African game farms, are giving new momentum to longer-running efforts to expand and formalize the game meat value chain. DFFE's growing emphasis on game meat under the NBES has added to this momentum. Additionally, recent economic instability in the industry, together with the onset of the COVID-19 pandemic, have created real challenges for game farmers, helping to draw still further support to game meat as a potential answer to the industry's difficulties. 


\subsection{Intensive and Selective Breeding}

Probably the most significant change in South Africa's game sector in recent decades is the emergence of what industry representatives term intensive and selective breeding. This refers to the deliberate selection of and breeding for specific animal traits, usually under controlled conditions. ${ }^{31}$ Intensive and selective breeding has frequently been applied to high-value species such as sable and buffalo, for example to maximize the animal's body size and horn spread. Farmers have also used the practice to produce large numbers of so-called colour morphs, wildlife with unique colour variations originally resulting from genetic flukes or mishaps. ${ }^{32}$

Intensive and selective breeding started as a niche activity but quickly became commonplace, occurring on $46 \%$ of game operations by $2017 .{ }^{33}$ The growth of the practice was closely linked with a remarkable rise in game prices. ${ }^{34}$ These pricing dynamics were driven by the hope that hunters would pay large sums to shoot rare and unusually coloured animals; however, by 2016 it had become evident that this hope was misplaced. ${ }^{35}$ What followed was a spectacular collapse in game prices, which Carnie suggests declined by as much as $85 \%$ for some species over a two-year period. ${ }^{36}$

Intensive and selective breeding remains a highly divisive topic in the wildlife sector. As but one example, the two major organizations representing game producers in South Africa - the South African Hunters and Game Conservation Association (SAHGCA) and Wildlife Ranching South Africa (WRSA) - fundamentally disagree on it. ${ }^{37}$ While this disagreement relates mainly to the potential repercussions of the breeding practices for animal genetics and the reputation of the South African hunting sector, there are also socioeconomic concerns. The collapse in game prices that some associate with intensive and selective breeding has hit the industry hard, especially since it was followed by the global COVID-19 pandemic (discussed further below). These shifts bear unevenly on different participants in the sector.

Despite its detractors, intensive and selective breeding appears to have gained legislative backing in 2019 through an amendment to the Animal Improvement Act by the Department of Agriculture, Land Reform and Rural Development (DALRRD) (then the Department of Agriculture, Forestry and Fisheries). ${ }^{38}$ Controversially, the amendment reclassified at least 32 wildlife species as farm animals, thereby permitting their "improvement" including for increased "production and performance" by licensed animal breeders. Responses to this amendment have been mixed. On the one hand, a group of 100 game farmers gathered some months after the amended Act was posted to establish species societies to regulate the newly listed animals. ${ }^{39}$ On the other, SAHGCA and local non-profit organization the Endangered Wildlife Trust (EWT) are currently pursuing legal action against the Department, in part due to the lack

31 Selier et al. (2018).

32 Some provinces banned the breeding and sale of colour morphs. For example, in KwaZulu-Natal, the provincial conservation body Ezemvelo KZN Wildlife controlled this tightly.

33 Taylor et al. (2020).

34 According to figures from WRSA (cited in Groenewald 2019), the price of sable rose by $479 \%$ and disease-free buffalo by $540 \%$ between 2009 and 2014. Colour morphs saw similarly astounding returns, with SAHGCA (cited in Carnie 2017) estimating that in 2012 growth on investment in yellow blesbok or golden gemsbok was above 400\%.

35 Instead, as two interview participants noted, intensive and selective breeding seemed to function something like a 'Ponzi Scheme', where breeders who took up the practice early on secured immense prices for the animals they bred, which they sold to other game farmers. These farmers in turn bred and sold off yet more animals to still other operations, in cascading effect. Eventually the market was saturated and hunters proved unwilling to pay the sums required to hunt the new animals, resulting in the price collapse.

36 Some breeders argue that a major drought beginning in 2015 in South Africa contributed significantly to the collapse in game prices: faced with having to buy fodder, some farmers were forced to sell their animals at any price. But many industry representatives consider that the problem is more fundamentally one of oversupply. In their view, breeders producing colour morphs in particular misjudged the consumptive demand for the resulting animals, creating a price bubble (African Indaba 2017, Carnie 2017).

37 SAHGCA's stance against the practice is congruent with that of the International Council for Game and Wildlife Conservation and the International Union for the Conservation of Nature. WRSA, by contrast, supports and publicly defends intensive and selective breeding. The Department has suggested that such amendment was necessary "due to changing farming systems in South Africa [where] game animals are already part of farm animal production systems in the country" (DAFF, cited in CAAWO 2019).

See: Lion Coalition (2019). 
of public consultation on the amendment and its potential conservation impacts. Indeed, Somers et al. identify numerous genetic, ecological, and economic risks associated with the new law, arguing that it conflicts with other biodiversity laws in South Africa. ${ }^{40}$

\subsection{Accelerating Conversions and New Investors}

The rise of intensive and selective breeding practices resulted in new actors entering game production in South Africa. The spectacular returns associated with game production from the mid-2000s attracted both existing farmers looking to diversify or expand their operations, and outside investors without prior experience in farming.

As in earlier periods, recent growth in the land area under game production has to a large extent been at the expense of land under livestock production. ${ }^{41}$ These conversions reflect challenging conditions in South Africa's livestock sectors, battered by a weakly valued currency, a long-lasting drought, fluctuating meat prices, and high input costs. While some conversions were driven by a sense of economic opportunity, still others were a matter of necessity. ${ }^{42}$ Distressed farms were scooped up by investors, a trend that scholars researching other agricultural sectors in South Africa have associated with economic 'financialization.' ${ }^{43}$

The entry of these powerful investors into game production has generated considerable press. Most famous among them is South Africa's president, Cyril Ramaphosa, whose outsized bids at wildlife

\section{Biodiversity Finance and the Game Sector}

The growing interest in biodiversity-related investments among international, institutional and individual financiers is seen as a major opportunity for the South African wildlife industry. Both the South African government and prominent conservation NGOs are actively recruiting financing from this sector.

For example, Conservation Outcomes, a local NGO working on conservation outside of state protected areas, secured a ZAR 2.1 million grant from the WWF-Nedbank Green Trust for a 'Demonstration Project to Catalyze the Game Meat Industry in South Africa' (2017-2020). The project assessed the market for game meat and aimed to develop guidelines for its production, harvesting and processing on communally-owned land. The organization used the grant as a springboard to develop its Harvest label, discussed later in this memo.

A still newer and larger project initiated by the South African government received funding of USD 9 million from the Global Environment Facility (GEF-7) and kicks off in 2021. 'Catalysing Financing and Capacity for the Biodiversity Economy' will develop and scale up lessons from a series of biodiversity economy nodes focused on supporting community stewardship and livelihoods. The five-year project will develop a system for sustainable off-take and harvesting procedures for game, and is jointly implemented by the DFFE, South Africa National Parks, iSimangaliso Wetland Park Authority, and the South African National Biodiversity Institute along with provincial conservation authorities in the Eastern Cape and Limpopo.

41 A large proportion of existing game farms in Limpopo, KwaZulu-Natal and the Northern Cape were previously cattle farms. In the Eastern Cape and the Karoo, in turn, sheep and goat producers have converted to wild game production. 
auctions on animals for his game farms earned him the nickname 'the buffalo'. ${ }^{44}$ It remains unclear what the collapse in game prices has meant for these new entrants and investors into the game sector. In a 2019 analysis for ABSA, one of South Africa's major banks, Cloete et al. suggested that the industry was seeing some consolidation, which the authors predicted would continue in the months to come. ${ }^{45}$

In addition, yet another sort of capital has entered the wildlife industry, this time from major international funders associated with 'biodiversity finance'. ${ }^{46}$ Driven by convictions that private finance can play an important role in conservation, biodiversity finance is a growing field involving international financial institutions such as the World Bank, non-profit organizations such as the Worldwide Fund for Nature (WWF), and philanthropic actors (see Text Box). While the qualitative orientation of these actors differs from that of game farmers and individual investors, their monies are becoming increasingly important in driving the overall direction of the wildlife industry.

\subsection{Changing Hunting Norms and Practices}

In parallel with changes to breeding, hunting norms and practices are also in flux. Recent years have seen heated debates around the ethics of trophy hunting, and in particular the breeding, keeping, and killing of animals in captivity in conjunction with the trophy market. Some see these practices as posing a serious reputational risk to the wildlife industry and more broadly 'brand South Africa.'

Given its spectacular reach in social- and mainstream media, few will not have heard of the case of Cecil the Lion, killed in Zimbabwe in 2015 by Walter Palmer, an American recreational big-game hunter. The case drew global attention to certain practices within the South African trophy market, including the presence of canned hunting and the captive lion sector. ${ }^{47}$ Importantly, many bona fide hunters condemn these practices, stressing that they eliminate the principle of 'fair chase' wherein an animal has a real chance of escape. Continued support for canned hunting led to the expulsion of two major hunting groups - the Professional Hunters Association of South Africa and the Confederation of Hunting Associations of South Africa - from the International Council for Game and Wildlife Conservation in 2017.

In early 2021, it seems that the captive lion sector may be reaching the end of its lifespan. Following its receipt of a High Level Panel of Experts report on practices and policies related to the breeding, hunting, trade and handling of elephant, lion, rhinoceros and leopard, DFFE has suggested that it will end captive practices for lions. ${ }^{48}$ Whether the properties involved will fade away or convert to other commercial wildlife uses remains to be seen.

Ramaphosa's personal profits from game farming stand in sharp contrast to the high levels of poverty and inequality in South Africa, resulting in criticism from members of the public and the political opposition (SAPA 2012; Smith 2014). Another prominent investor is Johann Rupert, a well known South African entrepreneur who owns, inter alia, Swiss and South African luxury goods companies and in 2013 was listed as the country's richest man (Slabbert 2013). Still another financing model saw established game producers secure investment capital from external investors keen to enjoy the financial benefits of game production without being involved in the dayto-day running of the farm. For example, one of our interview participants noted that he had deployed capital commitments from five external investors on his farm in recent years.

45 Cloete et al. (2019)

46 Rubino (2000).

47 Canned hunting refers to the hunting of put-and-take animals placed in an enclosure expressly for a hunting client. Researchers have traced how the captive lion sector, in turn, exploits animals over their full life span, from 'voluntourist' cub-raising initiatives, paid petting and photographic opportunities, to trophy hunting and supply of the international trade in lion bones (HLP 2020). Similar forms of exploitation apply to other wildlife species: from rhino orphanages where captivity for fundraising is prioritized over rehabilitation and release, to driven hunting where wildlife are herded into a narrow area flanked by stationary hunters, resulting in a large number of animal deaths (ibid.).

HLP (2020); Creecy (2021). 


\subsection{Emergence of Community Game Farms}

Alongside the expansion of private farms, recent years have seen the emergence of community game farms involving portions of South Africa's black majority. Community game farms are created through one of two main mechanisms: the first being the country's national land reform programs, and the second being biodiversity stewardship planning in South Africa's communal areas.

Land reform in South Africa consists of three programs, the most significant of which for the game industry has been the land restitution program. ${ }^{49}$ Community game farms created through land reform are particularly important in two provinces: Limpopo (where the majority of private game operations are also located, see Table 1) and KwaZulu-Natal. The limited academic work that exists on these ventures points to numerous problems related to their establishment and operation..$^{50}$ Many of these problems are also replicated on community game farms created through biodiversity stewardship planning in communal areas, lands that were historically classified as ethnic homelands (or bantustans) under the apartheid regime. ${ }^{51}$

In both variations, community game farms intersect with a broader issue in the wildlife sector: efforts to support black economic empowerment (BEE) through economic transformation. The aforementioned NBES sees the wildlife sector as having major transformative potential but recognizes that the current status leaves a lot to be desired. Indeed, in a 2018 presentation, DFFE went so far as to say that the fact the "sector remains untransformed" is its "biggest challenge."

\subsection{COVID-19 as a Game Changer?}

The aforementioned processes mean that game production has undergone a period of particularly rapid change in South Africa over the past two decades. But in the last few years, a series of crises has brought the sector nearly to a halt. The 2007-8 financial crisis led to a decline in international tourism and hunting. A long-lasting drought and the slump in game prices followed in 2015 and 2016 respectively. To this challenging situation we can now add the global COVID-19 pandemic and associated international travel bans and domestic lockdowns. These shut down trophy and biltong hunting, interrupted live sales, and closed hotels and hunting lodges for much of the 2020 hunting season, with little change thus far for 2021.

These measures have serious implications for game operations. WRSA assesses that its members have seen a high cancellation rate on confirmed bookings, massive decreases in both visitors and new bookings, a sizable drop in game sales and a loss of revenue from game meat sales. Adri Kitshoff-Botha, then the CEO of the organization, concluded that the South African wildlife industry was "on the brink of collapse" and that most participants in the wildlife industry would not survive the economic impacts of the pandemic in the absence of mitigation measures. ${ }^{53}$

49 Land restitution allows black communities who lost their land through racially discriminatory laws in the period after 1913 to lodge land claims with the government. If the claim is successful, the government purchases the land in question and compensates the landowner. The land is generally transferred to a Communal Property Association or Community Trust, an institution created to represent claimant beneficiaries and to manage (or participate in managing) the transferred farm. For an overview of the land restitution, land redistribution, and tenure reform programs under land reform, see: Hall (2004).

50 See in particular, Ngubane and Brooks (2013).

51 In communal areas, traditional chiefs or authorities - often the descendants of leaders hand-picked and favoured by the apartheid state - retain significant control over the land base. Communal lands can later be targeted by powerful conservation agencies working with the traditional authorities to develop protected areas for biodiversity stewardship.

52 DEA (2018a).

53 Kitshoff-Botha (2020). 
Employees on private game farms saw their wages reduced, were put on unpaid leave, or were made redundant, and associated industries (such as the professional hunting industry) saw their businesses evaporate. ${ }^{54}$ The impacts on community game farms have been equally profound. ${ }^{55}$

\subsection{A Game Meat Solution?}

The challenging circumstances facing game operators today constitute something of a watershed moment for the South African wildlife industry. Many participants are reflecting deeply on the industry's future, asserting the need to build back stronger after the COVID-19 pandemic. Game producers are actively exploring ways to make their operations more resilient. This has drawn new attention and supporters to the idea of formalizing and expanding the game meat value chain.

Proponents of an upscaled game meat value chain suggest that game meat production and processing should play a more prominent role in the industry's future going forward. To be sure, this is not an entirely new suggestion. For example, a 2006 report by the National Agricultural Marketing Council (NAMC) suggested that boosting public consumption of wildlife meat could help to both sustain the industry and support its expansion going forward. ${ }^{56}$ Similar messaging has been repeated in recent presentations by WRSA associates and in articles featured in that organization's magazine. ${ }^{57}$ The industry has also participated actively in several rounds of consultations on draft Game Meat Regulations promulgated by DALRRD (discussed further below). Nonetheless, the sense of urgency in recent discussions and debates around game meat in the wildlife sector has increased palpably.

Clearly, part of the impetus for a renewed emphasis on game meat is economic. The collapse of game prices and the decline in tourism due to COVID-19 have severely pinched revenues in the sector. Reduced revenues mean that game operations have less money to buy, feed, care for, and protect their animals; to pay staff and community beneficiaries; and to maintain their properties. ${ }^{58}$ Expanding game meat production creates a new marketing channel for surplus animals and a new income stream for game producers. ${ }^{59}$

There is also an ecological dimension to the game meat push. Even before the onset of the pandemic, key experts and representatives in the game sector were suggesting that at least some South African game farms were - in the words of Dr. Tertius Bergh, an independent meat safety consultant - "reaching and exceeding carrying capacity". ${ }^{60}$ The onset of COVID has worsened this problem. As then WRSA CEO Adri Kitshoff-Botha put it: "In the absence of a normal hunting season, wildlife ranchers will be faced with a challenge of overgrazing and over population of wildlife on their properties." As a result, "Animals need to be harvested." 61

Still others in the sector are motivated by a more long-term perspective or vision, government policy-makers among them. DFFE sees game meat production as a key component of the wildlife econo-

54 Ibid.

55 Take the case of Nambiti Private Game Reserve in KwaZulu-Natal, a game operation that was restored to the Elandslaagte community and is now under a co-management (or strategic partnership) arrangement with the former landowner. As reserve Chairman Clarke Smith (cited in Burke 2021) put it: "Reserves like ours went from quite a nice income supporting 300 jobs and a massive conservation project to literally nothing. We fell off a wall."

56 NAMC (2006).

57 Dry (2015); Zerbst (2017); Kitshoff-Botha (2018); Saayman and Slabbert (2018).

58 Baker (2020); Phillips (2020); Burke (2021).

59 Indeed, one of our interviewees suggested that in the current market, due to the costs of translocation and halt in live sales due to COVID-19 restrictions, animals are worth far more after slaughter for game meat than they are alive. For example, an impala prepared for sale as game meat is worth up to ten times more than the live animal, he estimated.

60 Bergh, cited in Phillips (2019).

61 Kitshoff-Botha (2020). 


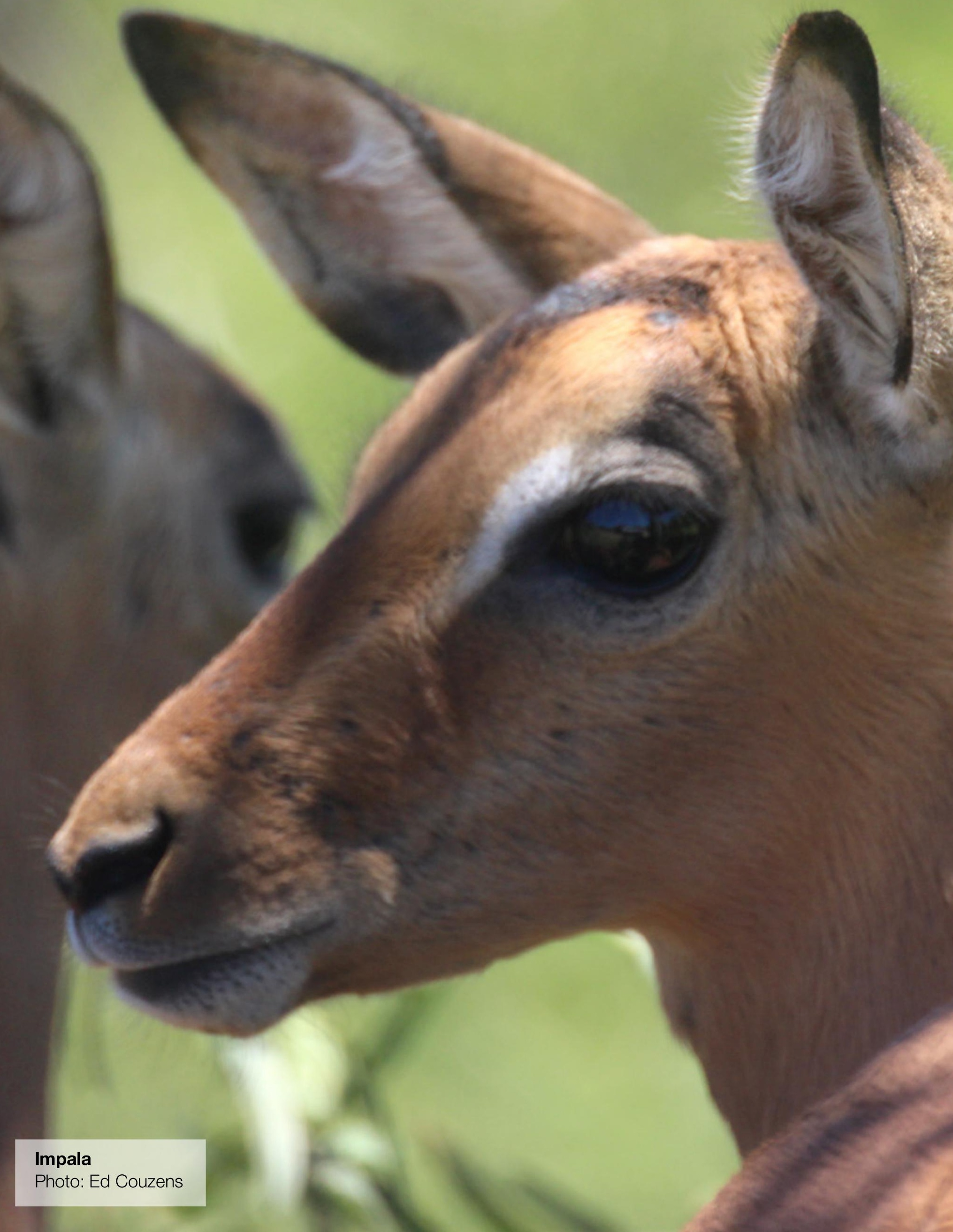


my, and an important mechanism for creating economic value and jobs in the sector. The Department suggests that revenues from game meat grew by 18\% per annum between 2008 and $2013 .{ }^{62}$ It assesses that South Africa could produce up to 60,000 tons of game meat per year by 2024 , given a projection that the total land available for game operations would increase by $50 \%$ during the same period. 63 As noted earlier, the Department has included formalizing the South African game meat value chain as an implementation initiative under the NBES (Figure 2), and is now developing a Game Meat Industry Strategy directed towards growing the industry as a pillar of the larger policy. ${ }^{64}$ Indeed, the Department's vision for 2030 is for the South African game meat industry to be "the world's preferred supplier of sustainably-sourced game (wild) meat."65

As for DALRRD, many game industry observers saw the aforementioned amendment of the Animal Improvement Act as being intended to support game meat production and processing. Indeed, certain game producers responded by establishing a 'Game Meat Value Chain Society' to develop a roll-out plan for such activities going forward. ${ }^{66}$ In 2020, the Department followed with a proposed amendment that would expand the list of species covered by the Meat Safety Act, a key piece of legislation governing game meat safety (discussed further below). Again, both SAHGCA and the EWT have filed legal cases against the Department over the Animal Improvement Act, and the latter has also expressed discomfort with the proposed Meat Safety Act change. ${ }^{67}$

The production of game meat thus seems to be gathering growing momentum at the present moment. Yet the process is not without its difficulties. The wide range of production practices and property uses that currently exist in the wildlife sector raise questions about the conditions under which game meat will be produced, and how to ensure that best practices are followed on all fronts. Such questions are particularly pressing in light of major regulatory challenges in the sector, and bring the need for serious reflection on concerns related to socioeconomic development and transformation, environmental sustainability, and human health and animal welfare conditions. We discuss these in the remainder of our memo.

\footnotetext{
DEA (2016b). breeding practices. This fear seems to be shared by some others in the sector. For example, the Endangered Wildlife Trust states in a recent publication that while it "wholly support[s] the move to create a legal framework to support the commercial sale of game meat from wild animals from natural free-living conditions, [it does] not support the intensive and selective breeding of wild animals in general, or for commercial meat production specifically" (EWT 2020).
} 


\section{The Regulatory}

\section{Framework for Game Meat Production}

The private wildlife sector is often referred to as a continuum, spanning everything from highly controversial practices such as 'canned hunting,' through to ecotourism-based operations where management interventions need to be as unobtrusive as possible and the operation run on sound ecological principles. The diversity inherent in the wide range of operations included under the 'wildlife sector' umbrella inevitably creates challenges for regulation. And as a relatively new sector, regulation has yet to catch up with the industry's expansion.

Wildlife production incorporates environmental, agricultural, health, tourism and land issues, but game meats are most strongly affected by regulations in the first three of these areas. Game operations are subject to both national regulations (see Text Box) and provincial regulations. At the same time, regulatory gaps mean that the sector is often left to self-regulate (and indeed to some degree may prefer its relative autonomy from government oversight). 


\section{National Legislation and Game Meat Production in South Africa}

The major pieces of national legislation which directly or indirectly affect game meat production include:

- National Environmental Management Act, 1998 (Act No. 107 of 1998)

- National Environmental Management: Biodiversity Act, 2004 (Act No. 10 of 2004)

- Animal Disease Act, 1984 (Act No. 35 of 1984)

- Animal Identification Act, 2002 (Act No. 6 of 2002)

- Animal Improvement Act, 1998 (Act No. 62 of 1998)

- Animals Protection Act, 1962 (Act No. 71 of 1962)

- Game Theft Act, 1991 (Act 105 of 1991)

- Marketing of Agricultural Products Act, 1996 (Act No. 47 of 1996)

- Meat Safety Act, 2000 (Act No. 40 of 2000)

- The Conservation of Agricultural Resources Act, 1983 (Act 43 of 1983)

- Veterinary and ParaVeterinary Professions Act (Act 9 of 1982)

\subsection{Overlapping Mandates and Capacity Limitations}

In South Africa, a ' $9+1$ ' system of collaborative governance means that in terms of conservation, responsibility is shared between the country's nine provinces together with the national government. Provinces must comply with and formulate regulations of equivalent strength to the relevant national legislation, which can be challenging. ${ }^{68}$

\section{At both levels of government, there is a potential clash of two major imperatives: the need to maintain biodi- versity integrity through nature conservation, and the economic drive to support revenues and livelihoods through trading in game and game products alongside ecotourism. ${ }^{69}$ Broadly, those government departments responsible for the environment tend to advance the former perspective, while those responsible for agricul- ture favour the latter. ${ }^{70}$}

Recently, this has led to something of a standoff in the sector, as game producers who view their operations as a form of agribusiness motivated by a profit imperative seem to have gained increasing recognition from DALRRD. The Department's recent amendments to the Animal Improvement Act and its proposed amendment to the Meat Safety Act (discussed above) are viewed by some as being one example of this. An interview participant suggested that DALRRD's apparent support for community game farms acquiring animals produced through intensive and selective breeding is a second example.

A final issue compromising government mandates relates to severe constraints in budgets and capacity, especially at the provincial level. Provinces are tasked with implementing and enforcing national regulation but without the funding this requires. Indeed, many

The result is a lack of legislative coordination and harmonization, meaning that major inconsistencies sometimes exist (HLP 2020). A case in point is the permit system regulating the movement of protected species between locations, which being paper-based is also outdated, slow, and cumbersome.

69 Kamuti (2014); Taylor et al. (2016).

70 Complicating the situation, the relevant national government departments have undergone repeated restructuring together with changes in title and mandate. For example, under the current administration of President Cyril Ramaphosa, agriculture is now part of a Department of Agriculture, Land Reform and Rural Development (DALRRD), rather than with forestry and fisheries as in recent years. The current Department of Forestry, Fisheries and the Environment (DFFE) was in the past the Department of Environmental Affairs (and for some years the Department of Environment, Forestry and Fisheries, a different acronym). In contrast to the current DALRRD, there was a separate Department of Rural Development and Land Reform during the President Jacob Zuma administration, which had previously been called the Department of Land Affairs. 
conservation and other state authorities have experienced sharp cuts in recent years, leading to an erosion or loss of relevant expertise, skills, and institutional memory. ${ }^{71}$

\subsection{Game Meat Safety as a Regulatory Gap}

One of the most challenging areas with respect to regulating game production is in regard to game meat safety. In South Africa, meat production is covered under the Meat Safety Act. While the Act provides separate regulations for each different category of meat produced in South Africa, the regulations for game meat have been stuck in draft form since $2004 .^{72}$

The lack of clear Game Meat Regulations presents a major hindrance to business growth and to the expansion of production on wildlife sector properties. Most operators in the game industry are not clear about how to implement the Act's requirements and are left to interpret the relevant regulations themselves.

The challenge with respect to meat safety arises due to the way that game meat makes its way to market in South Africa. There are two main pathways. The first pathway consists of meat harvested by local hunters. In addition to the meat they harvest for their own personal consumption (and that of their family and friends), these hunters frequently supply carcasses into the retail market. ${ }^{73}$ In many cases animals are dressed in the field before being further processed at the hunter's home; at an unregistered abattoir facility that may exist on the property in question or another nearby property; at one of the 'rural throughput' abattoirs that are registered with DALRRD; and/or through local butcheries. ${ }^{74}$ From there the resulting game meat cuts and products are sold onwards to retailers, end-use restaurants and consumers. Industry analysts generally agree that the great majority of game meat appearing in butcheries is supplied through this pathway - after consulting with key experts Taylor et al. put the figure at 95\%, while the consultants developing the new Game Meat Industry Strategy are using a figure of $92 \% .^{75}$

The Meat Safety Act requires that domestic meat value chains have food safety inspections. Abattoirs on a given game farm are permitted to accept partially dressed carcasses of animals killed on the same property. Abattoirs accepting animals from other premises are meant to ensure that the said animals are accompanied by an inspection report. However, few if any local hunters engage meat inspectors during their hunts, and as noted above carcasses may be delivered directly to local butcheries without

71 For example, in 2020 one province lost $93 \%$ of its budget for conservation, leaving some programs operating at a $70 \%$ vacancy rate (HLP 2020). Such cuts may also compromise objectives besides conservation. For instance, we learned in our interviews that Ezemvelo KZN Wildlife used to have some 40 game meat inspectors on staff, but that these positions were eliminated in a budget cut, raising serious concerns related to game meat safety and human health.

72 One of the points preventing promulgation of the regulations is the requirement for a legislative amendment to the Act, which currently prohibits abattoirs from receiving and processing dead animals. While DALRRD exempted game animals from this and certain other provisions of the Act in 2016, the legislation has not yet caught up. In practice, game animals are typically shot in the field and a document called a 'transferrable depot' allows operators to make a preliminary treatment of the carcass before transporting it to a processing facility. This means that game abattoirs are only required to have slaughtering facilities if they also want to also deal with livestock. It similarly allows for one abattoir to service multiple game properties.

73 As one respondent put it, this means that the 'own consumption' designation is sometimes misused since some of the animals originating from this practice do in fact enter the retail market.

74 Taylor et al. (2016) suggest that the number of registered game meat abattoirs in South Africa is not known precisely. They provide approximate figures, categorized by the number of slaughter units as follows: 4 High throughput abattoirs (unlimited slaughter units); 9-15 Low throughput abattoirs (3-20 slaughter units); 6-12 Rural abattoirs (1-2 slaughter units). As for unregistered game meat abattoirs, it is unknown how many of these exist in South Africa. One of the participants interviewed for our research suggested that while most large private reserves have an abattoir in order to process offtakes, many of these facilities appear to be under-utilized and/or falling into disrepair. DFFE indicated in 2017 that the Department planned to have at least 110 game meat processing facilities in place by 2021, but it is unclear how much progress has been made on this goal (DEA 2018a).

75 Taylor et al. (2016); pers.com. Alsson, personal communication, 14 July 2021. Meat derived from this pathway is referred to in the industry as 'grey meat'. 
passing through a registered abattoir and therefore an inspection process. This means that a sizeable proportion of the game meat that ends up on South African dinner plates is uninspected, which raises food safety concerns. ${ }^{76}$

The second pathway through which game meat enters the market in South Africa arises from commercial harvesting activities, typically undertaken on relatively larger or more established game farms. At least some of these operations are members of an organization called the Game Abattoirs and Meat Establishments of South Africa (GAME SA). Meat produced by GAME SA members is harvested through culling undertaken by professional harvesting teams, who are registered with DALRRD. ${ }^{77}$ The resulting game meat may be processed and sold through domestic channels, including both larger grocery retail chains (for example Checkers, Pick n Pay, Woolworths), as well as smaller specialty shops and restaurants. ${ }^{78}$ The meat may also be exported, although presently the export of meat from cloven-hooved animals is banned due to the presence of Foot and Mouth Disease (FMD) in South Africa. ${ }^{79}$

GAME SA indicates that meat produced by its members through commercial harvesting is subject to an inspection protocol. Inspectors are present at both the field abattoir where the preliminary processing of carcasses occurs and at the cutting plant. ${ }^{80}$ The organization uses a tagging system to ensure traceability of the product 'from farm to fork' ${ }^{81}$ Although meat produced for the domestic market through this channel is technically subject to the national Meat Safety Act, the absence of formalized Game Meat Regulations presents an obstacle. Industry analysts suggest that in practice, such meat is slaughtered and processed in accordance with the guidelines of the Veterinary Procedural Notices (VPNs), issued and amended regularly by DALRRD in conjunction with the European Union (representing importing countries). ${ }^{82}$ The VPNs, which were initially developed for game meat going to export markets, are also applied to the limited volume of game meat that continues to be marketed through export channels. ${ }^{83}$

\subsection{Private Standards and Industry Certification Schemes}

Frustrated by the delays in finalizing the draft Game Meat Regulations, some industry participants are taking matters into their own hands. As an interim solution, WRSA established a private standard for game meat production. DFFE, in turn, is focusing on creating a voluntary industry certification scheme. WRSA's private standard guides the production of game meat from ranch to consumer and was successfully registered with the International Standards Certification, a globally accredited certification body, in 2015. ${ }^{84}$ The standard was effectively designed to function as a private game meat scheme for commercial production purposes. WRSA ensured that the document complied with South African legislation in order that the government could not object to it. Although the association evidently planned that this would help ensure that South African game meat could be sold through major retailers, ${ }^{85}$ the standard is apparently not in use today and commercial production is rather following the process outlined above.

76 Van der Merwe et al. (2011) suggest that game meat harvested through this first pathway may, for example, be characterized by higher carcass temperatures and higher microbial loads relative to that produced through commercial harvesting for export markets.

77 For further details of the GAME SA harvesting process, see: https://www.gamesa.co.za/harvesting-process. Culling is itself an increasingly professionalized activity. For further details, see: https://www.pcoasa.co.za/

78 Charl de Villiers, head of the game marketing division at the Mosstrich Group (cited in Uys 2016) suggests that while supermarkets used to buy from local hunters, they have become pickier in the wake of food mislabelling scandals and now prefer to buy from registered sellers.

79 Presently only ostrich and zebra meat are exported from South Africa, due to the FMD ban. The current ban has been in place since 2019 due to an outbreak of FMD in cattle. A previous ban was in place from 2011 until 2014.

80 See: https://www.gamesa.co.za/harvesting-process

81 Ibid

82 Alsson, personal communication, 14 July 2021.

83 Van der Merwe et al. (2011).

84 Zerbst (2015) provides an overview of the WRSA standard.

85 Ibid. 
Certification schemes in turn provide a different means for quality assuring game meat going to end use consumers. Presently, DEFF is working with the United Nations Development Programme (UNDP) to develop a national voluntary certification scheme for the wildlife sector. According to the Department's proposal and a subsequent discussion document, certification will be market-based and supported by key sector stakeholders. ${ }^{86}$ The overall aim is to "incentiviz[e] environmentally and socially sustainable practices and contribut[e] to biodiversity conservation." ${ }^{87}$ Nonetheless, some of our interviewees were sceptical that the scheme would yield economic results. ${ }^{88}$ In a parallel process, a large conservation NGO is pursuing a private label as a means of marketing sustainably-produced game meat (see Text Box).

\section{The Harvest Label}

The lack of legal compliance in game meat production has prompted Conservation Outcomes (CO), a non-profit organization, to develop a branding strategy for game meat that will be known as Harvest. This brand will be supported by a national protocol audited by the South African Meat Industry Company, a quality assurance company created by the Red Meat Industry of South Africa. Auditing will occur at both the farm and processing (abattoirs/butcheries) level and may expand to retail in the future.

CO hopes to align the label with the categories used in the South African National Biodiversity Institute's Biodiversity Stewardship Programme, meaning that it will focus on game operations that are in designated protected areas or on properties considered to be employing 'other effective conservation measures' under the terms of the Convention on Biological Diversity (CBD).

Culling at these operations will follow the code of conduct established by the Professional Cullers Association of South Africa, which requires that the animal should be killed as quickly as possible to minimize any pain and suffering.

Beyond the achievement of industry compliance with health and safety requirements and assisting with the marketing of branded products, Harvest will ensure that communities participating in the wildlife economy and those located adjacent to accredited operations benefit from game meat markets. According to $\mathrm{CO}$, Harvest holds the potential to generate new income streams for these communities. It may also help to overcome marketing challenges associated with the seasonal and sporadic availability of game meat by involving a large number of producers. This will be reflected through the creation of geographically-specific brands of origin such as Harvest-Kruger and Harvest-Zululand.

\section{UNDP (2018); DEFF (2020b)}

87 Secondary goals include: "increas[ing] the amount of land in the wildlife sector; encourag[ing] sustainable practices in the wildlife sector, and increasing private wildlife ranchers' contribution to biodiversity conservation (species and landscape level); provid[ing] a systematic means of improving industry reputation; and stimulat[ing] inclusive growth in the industry". See: DEFF (2020b).

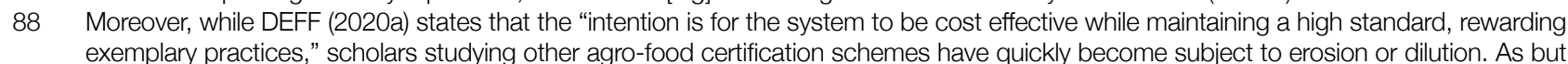
exemplary practices," scholars studying other agro-food certification schemes have quickly become subject to erosion or dil
one example, see: Buck et al. (1997) and Guthman (2004) on the 'conventionalization' of organic production. DEFF (2020b). 


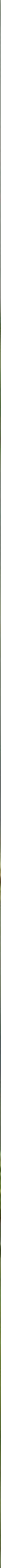




\section{Game Meat Value Chain Challenges}

COVID and price-related instability appears to be bolstering efforts to make game meat a more prominent part of the wildlife sector going forward. As researchers and commentators in this field, we see several potential dangers associated with this trend. Without careful thought and action, we argue, increasing game meat production risks locking in some of the more undesirable conditions in the wildlife sector with respect to socioeconomic development, environmental sustainability, and human health and animal welfare conditions. Expanding the game meat value chain could also create new problems for the wildlife sector in these and other areas.

\subsection{Socioeconomic and Transformation Challenges in the Game Meat Value Chain}

The wildlife sector has emerged as a key industry in rural South Africa. WRSA asserts that alongside the sector's contributions to the national GDP (discussed earlier), game operations support some 140,000 
jobs, although Taylor et al. put the number closer to $65,000.89$ DFFE suggests that this number could climb to 100,000 jobs by $2030 .{ }^{90}$ Yet the fact that the sector remains heavily white-dominated more than 25 years after the end of apartheid is cause for concern, particularly given the entrenched poverty experienced by South Africa's black majority. This raises complex issues with respect to land and land reform as well as the participation of black South Africans in the game meat value chain going forward.

One area of concern is that while private game farms and reserves are the base unit of game meat production, their establishment has often involved the displacement of black farm dwellers or "labour tenants.' Although these people may have resided on the farm for their entire lives, their labour is not needed following conversion and they are often relocated. This displacement and the associated devastation of livelihoods often goes unrecognized by game sector proponents, and tenant rights have not been well protected by the state. ${ }^{91}$

So-called community game farms, too, are not without problems. While South Africa's land reform programs can provide redress to dispossessed or 'previously disadvantaged' communities, they face many challenges. Firstly, the complex and contested nature of rural histories and identities is often disregarded by planners and state actors, who use the word 'community' without specificity in reference to all rural black South Africans. ${ }^{92}$ Secondly, when restoring land that has already been converted to game farming, the state insists that beneficiaries continue with this land-use regardless of their actual wishes, compromising beneficiary autonomy. ${ }^{93}$ And thirdly, local decision-makers and elites may use state-led land reform and biodiversity stewardship planning processes to gain further power and entrench their control. ${ }^{94}$

Game farm beneficiaries have experienced a serious lack of post-settlement or post-designation support. One problem has been that the state is unwilling to pay out for the animals when acquiring the property. ${ }^{95}$ This lack of state support extends to training and access to finance or markets - areas that are obviously required for a successful game operation. Many projects have unsurprisingly 'failed' in commercial terms.

For some years, the South African government has sought to address these challenges by implementing 'strategic partnerships', co-management arrangements, or joint ventures pairing communities with established game operators or businesses. Unfortunately, similar arrangements in other sectors have often worked to, in effect, funnel income away from beneficiaries. ${ }^{96} \mathrm{It}$ is unclear whether the same trend prevails in the game sector. More recently, political heat around the land reform issue has led to calls for land expropriation without the payment of compensation, a possibility to which game operators have had a negative response..$^{97}$

89 Dry (2015); Taylor et al. (2016).

90 DEFF (2017).

91 See: Brooks and Kjelstrup (2014) for farm dweller removals and tenure rights. Subsequent job creation on wildlife properties may not target these displaced farm dweller populations, since different skills and often educational levels are required for working in the wildlife sector; see: Brooks et al. (2011) and Spierenburg and Brooks (2014).

92 Planners and policy-makers thus frequently fail to understand the particularities of the claimant histories involved. See: Ngubane and Brooks (2013) for further comments on this phenomenon and arguments as to why a more nuanced view is needed.

93 Such concern deepens under a recent reformulation of land reform policy, wherein the government is no longer transferring land title to beneficiary communities, preferring to rather issue long term leases that do not convey full ownership.

94 Whether it is traditional authorities or other local elites who see an opportunity for personal benefit at the expense of 'community' members, such actors must be held accountable. Government authorities and conservation groups should be more aware of these dynamics because they can lead to socially unjust outcomes.

95 Game farmers have been known to relocate or shoot all their game prior to land transfer. It is clearly not possible to continue to run a game farm on which there is no wildlife and restocking often proves impossible given the cost of the animals. Should game remain on the farm, there is often little expertise or ability to manage it properly, and animals may soon fall prey to poaching or local hunting. While provincial conservation authorities and South African National Parks have recently established game 'donation' and 'loan' programs supplying surplus animals to communities, it remains unclear if these are sufficient in scale.

96 See: Derman et al (2010); Lahiff et al. (2012); Sommerville (2019).

97 The South African parliament is currently hearing public comment on a new Expropriation Bill and working on amendments to a related section (Section 25) of the country's constitution. See WRSA (2018) for the Association's views on the matter. 
The problems of transformation extend beyond land into other parts of the wildlife sector. While DFFE has set ambitious targets related to the topic in its Biodiversity Economy Lab (Figure 2), some suggest that the state and industry partners are still not doing enough. There remains a tendency to avoid conversations about transformation at high levels in the game industry because they are uncomfortable for many people. Keeping the issue on the agenda has often proved frustrating. ${ }^{98}$ Respondents from the African Game Ranchers Association and the South African Black Hunters and Sport Shooting Association cited the fact that the concerns, experiences and perspectives of black South Africans were going unaddressed within established industry bodies as their principal reason for starting their respective associations.

Frustration also surfaces over the fact that the government's stance on transformation appears reactive rather than forward-thinking. Questions as to where black ownership should be focused in both the broader wild life sector and the game meat value chain in particular have yet to be fully addressed.

For instance, one respondent noted that an early focus on training professional hunters had not borne fruit because they are not finding work. ${ }^{99}$ Advice that communities acquire animals produced through intensive and selective breeding (a practice that DFFE is still encouraging, according to one interviewee) may be especially damaging to the interests of new game farmers, since the market for these animals has collapsed. Another respondent suggested that DFFE seemed to be targeting the development of new game meat processing facilities for black ownership but was sceptical that community-owned abattoirs would generate meaningful economic returns. Many existing facilities appear to be in disuse or losing money; and as in any value chain, value in the game meat chain would tend to accrue mostly at the further processing and retailing stages.

In addition to understanding the relative income-generating potential at different stages of the value chain, one must equally keep in mind how the different stages sum together to produce economically viable - or conversely, marginal - game operations. For example, an established game farmer may be able to tolerate lower returns derived from game meat provided that they obtain high returns from tourism and hunting activities. By contrast, a community whose sole activity is game meat production will not fare as well. Add to this the economic disruptions of COVID-19 (which have hit those without a diversified income stream or economic 'cushion' the hardest), and it is easy to see how some of those who are the 'last in' to the industry may quickly become the 'first out.' It seems clear that further thought and planning is required if the initiatives mentioned here and others are to achieve success.

\subsection{Environmental Sustainability and the Game Meat Value Chain}

The South African wildlife sector trades on the strength of its green credentials, with participants frequently asserting their contributions to biodiversity conservation. To be sure, experts agree that the allocation of ownership rights over wildlife has resulted in at least a 10-fold increase in wildlife numbers in

98 For example, the South African Black Hunters and Sports Shooting Association (SABHSSA) initially participated in the Wildlife Forum, a cross-party group established by DFFE to help direct the wildlife sector. But after some time they elected to withdraw, feeling that their perspective was going unheard and transformation pushed off the table.

99 One respondent suggested that there seemed to be a lack of broader commitment within the industry to support these new entrants and help them build their client networks. Another suggested that even before the onset of COVID-19, the number of international hunters arriving in South Africa was too small to support an ambitious training program of this nature. In the meantime, there remain very few black outfitters in the country - one interview participant put the number at fewer than five. And blacks in the recreational hunting industry similarly assert that they face prejudice and discrimination when hunting on white-owned farms.

100 Some suggest a much larger increase in wildlife populations. Du Toit (2007) suggested that there were as many as 18.6 head of wildlife on private lands, while Taylor et al (2016) put the number of herbivores at just under 6 million. Both authors use the estimate (reported in Du Toit 2007) of 575,000 head of game on private land in South Africa in 1966. 
South Africa. ${ }^{100}$ WRSA representatives frequently assert that private ranching has played a major role in helping the recovery of threatened and endangered species beyond state protected areas. ${ }^{101}$ Although at least one recent survey has tried to identify the range of different wildlife species found on game operations, it is difficult to put the resulting lists into a conservation perspective. ${ }^{102}$ Scientific studies documenting the conservation impacts of private wildlife ranching are few. ${ }^{103}$

This acknowledged, the presumed 'net positive' contribution of the wildlife sector to biodiversity conservation is disputed. ${ }^{104}$ There is of course enormous variation across the sector. Where intensified game production has occurred, negative environmental impacts are clearly evident. It is possible that these impacts could become exacerbated in an expanded game meat value chain. Indeed, one interview participant expressed concern that the turn to game meat could kick off a new round of intensive and selective breeding in the wildlife sector, which could be detrimental to both environmental and socio-economic conditions therein. ${ }^{105}$

A first issue concerns land-use change and carrying capacity. The fencing practices that even large wildlife reserves rely on compartmentalise and fragment the landscape, restricting the movement of free-ranging species and their access to habitat. ${ }^{106}$ Intensive and selective breeding introduces a parallel intensification of land use, driving concerns around overstocking especially after the 2020 hunting season closure. In studies from over 10 years ago, researchers were already problematizing the small and enclosed nature of many game ranches in South Africa, which then ranged in size from 8.2 to 49.2 $\mathrm{km}^{2}{ }^{107}$ The situation has apparently worsened, with Taylor et al. calculating that approximately 6\% of the total land base devoted to wildlife production in South Africa is now contained within intensive breeding camps. ${ }^{108}$

A game meat value chain potentially linked to intensive and selective breeding practices also raises further environmental concerns. These breeding practices may introduce 'invasive' or 'extralimital' species into areas beyond their natural ranges, impacting ecosystem functioning. Rare species (or those with small naturally occurring populations) may be threatened in both South Africa and other African countries where sourcing is often cheaper. Intensively breeding a small pool of animals serves to fix particular genetic traits and may allow mutations to accumulate, driving overall losses in genetic diversity, reproductive potential, fitness, and adaptive capacity for the species. And interrupting the natural evolution of the relationship between hosts and diseases or parasites may lead to decreased resistance within game populations. ${ }^{109}$ For these and other reasons, scientists question the actual conservation value of wildlife that is produced through these breeding practices. ${ }^{110}$

The proliferation of game farms similarly alters game population dynamics and predator control. Single species breeding camps clearly do not resemble natural ecological habitats which commonly feature a range of prey and predator species that help to balance each other. Game production favours ungu-

101 See for example: Dry (2016).

102 See Taylor et al. (2016).

103 In Taylor et al. (2016), the authors summarize the literature on privately protected areas (PPAs) as follows: "Gallo et al. (2009)...found that PPAs contributed to the conservation of otherwise underrepresented biomes, and Shumba et al. (2020)...showed that PPAs, including ones with informal status such as wildlife ranches, can be effective in conserving natural land cover and biodiversity intactness. Additionally, Clements et al. (201[9]) showed that PPAs could facilitate the persistence of large mammals."

104 Game operators today often argue that much of South Africa's land is marginal and hence unsuitable for arable agriculture or livestock production. They assert that wildlife ranching is a beneficial land use that returns land to its natural state, restoring its biodiversity (Kamuti 2015). For a critique of such messaging, see Davies-Mostert (2014).

105 Other respondents countered that the majority of game meat will be sourced from extensive game operations where intensive and selective breeding is less of an issue.

106 Selier et al. (2018).

107 Cousins et al. (2008); Lindsey et al. (2009)

108 Taylor et al. (2016).

109 Selier et al. (2018) provide an in-depth discussion of these and other issues.

110 Taylor et al. (2016). 
late species, some of which are regarded as high-value species such as the sable or roan, leading to instances of what Cousins et al. call predator persecution. ${ }^{111}$ Such practices evidently became more common during the period of high game prices prior to 2015. ${ }^{112}$ An expanded game meat value chain may potentially exacerbate these ecological disruptions.

\subsection{Health and Welfare Concerns Related to the Game Meat Value Chain}

Consumers and regulatory bodies are placing increased pressure on producers to provide meat - including game meat - in a safe and ethical manner. Compliance will require a focus on disease and food safety, as well as animal welfare, at various points of the supply chain.

Since 2019, an outbreak of Foot and Mouth Disease (FMD) has highlighted the risks posed by certain diseases that are known to occur in game animals (Table 3). Although the outbreak originated in cattle, it resulted in the shutting down of exports of game meat derived from cloven-hooved animals in South Africa, since affected areas must be quarantined and animals or meat harvested must not be moved outside of control zones. ${ }^{113}$

The emergence of the COVID-19 pandemic has heightened concern over the potential risks posed by zoonotic diseases (diseases that can be transmitted from non-human animals to humans). Since wild animals are reservoirs for pathogens, human contact with their bodily fluids may transmit zoonoses. ${ }^{114} \mathrm{It}$ is possible that concerns over these perceived health risks - even if they are inaccurate or exaggerated - may lead to opposition to game meat consumption, resulting in reduced wild meat sales. ${ }^{115}$

There are specific concerns about how game meat is handled in South Africa and associated risks to human health. Game animals are typically slaughtered and their carcasses undergo an initial cleaning in the open veld, presenting opportunities for contamination. There can be problems related to slow bleeding and delays between the time of slaughter and the animal's arrival at an abattoir where it can be chilled for further processing. ${ }^{116}$ The absence of finalized Game Meat Regulations under the Meat Safety Act, the limited inspection capacity available, and the fact that a sizeable proportion of game meat enters the domestic market uninspected, does little to assuage concerns in this regard.

Nonetheless, from a health perspective many consider game meat to be superior to other protein sources currently available to consumers. Game animals feed almost exclusively on natural vegetation and lead a more active life, giving game meat a high protein and relatively low fat content and making it a good source of zinc and iron. ${ }^{117}$ Yet game meat consumption remains relatively low among South

111 Predator persecution refers to the targeted killing of predators to reduce their numbers and subsequent impact on livestock or game animals (see Cousins et al. 2008; 2010). In addition to disturbing natural population dynamics, predator removals may disrupt the social structures in predator communities, decreasing their survival rate and conservation status (Selier et al. 2018).

112 Pirie et al. (2017).

113 FMD is not communicable to humans but affects both livestock and game species such as African buffalo, kudu, impala and nyala, making contact between the two categories dangerous when one is known to be infected. In case of severe outbreaks mass slaughtering of infected animals may be required, which has the unintended consequence of producing economic losses for game and livestock farmers. As noted earlier, ostrich and zebra meat are not affected by the ban.

114 Ahl et al (2012), cited in Hoffman et al. (2017), assert that the majority of human zoonotic infections occur through handling of infected animals or carcasses and consumption of infected meat. In response to this risk, some prominent NGOs have called for a ban on the commercial use of wildlife for human consumption (see Peros et al. 2021 for a pertinent review). However, one respondent countered that he knew of no reports of disease transmission under extensive models of game transmission. Rather, disease occurrence and transmission seems mostly to occur where animals live or are housed in large numbers in cramped conditions.

115 According to McNamara et al. (2021), this is likely to be accompanied by a fall in commodity prices and a disruption of existing supply chains.

116 Van der Merwe et al. (2011); Phillips (2019).

117 Wertheim (n.d.). 
Africans. While many snack regularly on dried products such as biltong and droëwors, consumption of fresh meat is less common except perhaps among hunters. ${ }^{118}$ While game meat is often promoted as a delicacy and has a higher price point than other meat options, industry proponents nonetheless suggest that the product can contribute significantly to achieving food security. ${ }^{119}$

During our interviews, two respondents suggested that at present, game meat may have limited appeal particularly to consumers who have never consumed it before and those who can not afford its relatively high price point. ${ }^{120}$ Marketing efforts must be cognizant of and designed to address this to increase consumers' awareness of the product and so expand the market. ${ }^{121}$

Animal welfare concerns also feature prominently in the game meat value chain. Global animal rights groups are becoming more visible in their campaigns for justice and protection for sentient creatures. In South Africa, the National Council of the Society for the Prevention of Cruelty to Animals (NSPCA) is the agency authorized under the Animals Protection Act. Already an under-resourced agency, the NSPCA is being asked to perform a growing number of inspections on game farms and has in fact laid charges against prominent game operations in recent years. ${ }^{122}$ The rise of more intensive models of game production at some operations presents particular challenges requiring special attention, for example around animal confinement, overstocking, underfeeding, and unsafe transport conditions.

118 A recent survey by Saayman and Slabbert (2018) on behalf of WRSA assessed the meat purchasing behaviour of consumers in South Africa. The survey found that consumers generally preferred beef, followed by mutton and game meat, as meat sources. Those who reported consuming fresh game meat did so because of its unique taste, the fact that it is healthy, and that it contributes some variety to the dinner table. Respondents who did not consume game meat reported a lack of familiarity with the product and its means of preparation, as well as its irregular availability.

119 See for example, Kitshoff-Botha (2018).

120 It is not impossible that black middle-class urbanites may associate game meat or venison with 'bush meat' and therefore do not see it as an aspirational food type. More importantly, perhaps, they lack familiarity with the product. Whilst at the 'high end', game meat is popular with some well-heeled urban consumers; and at the 'low end', many rural people enjoy it; one of our respondents referred to a 'missing middle' demographic that remains to be convinced. This group of meat eaters may have reservations about the edibility and affordability of venison, preferring the more standard beef and chicken. Knowledge on how to properly cook or prepare game meat is also lacking, it was noted.

121 For example, Saayman and Slabbert (2018) recommend working with restaurants to offer game meat dishes as a preferred option, making ready-to-cook options widely available in supermarkets, and promoting television cooking demonstrations led by celebrity chefs.

122 On the cruelty charges, see NSPCA (2019a). The NSPCA has also been outspoken in its concern around captive lions and similar operations. In 2019, the Pretoria High Court ruled in the agency's favour in a case brought against the South African Minister of Environmental Affairs regarding lion bone quotas set for 2017 and 2018. The judgement ruled that the quotas were unlawful as the DEA had not considered animal welfare (which the department argued was not part of its mandate) (see NSPCA 2019b). Widely considered to be precedent-setting, the judgement has important implications for all forms of wildlife trade and consumption, including game meat production. 


\section{Table 3: Selective Summary of Diseases Affecting Game in South Africa}

\begin{tabular}{|c|c|}
\hline Disease & Species affected \\
\hline African horse sickness & Zebra (Equus quagga) \\
\hline African swine fever & Warthog (Phacochoerus africanus) \\
\hline Anthrax & Kudu (Tragelaphus strepsiceros) \\
\hline Avian Influenza & Farmed and wild ostriches (Struthio camelus) \\
\hline $\begin{array}{l}\text { Bovine tuberculosis (My- } \\
\text { cobacterium bovis) }\end{array}$ & $\begin{array}{l}\text { Buffalo (Syncerus caffer), kudu (Tragelaphus strepsiceros), } \\
\text { impala (Aepyceros melampus) and warthog (Phacochoerus } \\
\text { africanus) }\end{array}$ \\
\hline Brucellosis & $\begin{array}{l}\text { Buffalo (Syncerus caffer), eland (Taurotragus oryx), impala } \\
\text { (Aepyceros melampus), sable antelope (Hippotragus niger } \\
\text { niger), waterbuck (Kobus ellipsiprymnus) and zebra (Equus } \\
\text { quagga) }\end{array}$ \\
\hline $\begin{array}{l}\text { Cyanobacterial intoxica- } \\
\text { tion }\end{array}$ & $\begin{array}{l}\text { Wildebeest (Connochaetes), zebra (Equus quagga), white } \\
\text { rhino (Ceratotherium simum), buffalo (Syncerus caffer), } \\
\text { giraffe (Giraffa camelopardalis) and warthog (Phacochoerus } \\
\text { africanus) }\end{array}$ \\
\hline Foot and Mouth Disease & $\begin{array}{l}\text { African buffalo (Syncerus caffer caffer), bushbuck (Tragela- } \\
\text { phus scriptus), giraffe (Giraffa), impala (Aepyceros melam- } \\
\text { pus), kudu (Tragelaphus strepsiceros), nyala (Tragelaphus } \\
\text { angasii) and warthog (Phacochoerus africanus) }\end{array}$ \\
\hline Rift Valley fever & Buffalo (Syncerus caffer) and gemsbok (Oryx gazella) \\
\hline Trypanosomiasis & Antelope and buffalo (Syncerus caffer) \\
\hline
\end{tabular}




\section{Insights from the Emerging Game Meat Value Chain}

One of the most useful aspects of a memo of this sort is the practical advice it can provide to those involved in the sector. The recommendations that follow are based on up-to-the moment interviews conducted with participants from across the sector, combined with our own knowledge and insight into the field. As outlined earlier, there are important social, environmental, and health and welfare concerns related to the game meat value chain that remain unaddressed at the present time. It will be difficult to move forward in an inclusive, sustainable, safe, and ethical manner without progress on some of these issues. We therefore make six practical and targeted recommendations that are intended to advance and inform planning in this regard. We hope that these recommendations will be given serious consideration should sector participants continue to pursue the expansion of the game meat value chain in the hopes of harnessing economic growth. 


\subsection{Advice for Front-Line Persons and Policy Makers}

\section{Recommendation 1: Conduct an up-to-date survey of the extent of the game sector.}

Currently it is very difficult to determine the nature and scale of game farming in South Africa with any certainty. The most recent study (that of Taylor et al.) is based on a partial sample and does not take account of recent developments such as the collapse in game prices and the emergence of COVID-19. ${ }^{123}$ It is difficult to address challenges in the sector without knowing how widespread they are. As one of our respondents highlighted, "you can't manage what you don't measure."

We recommend that DFFE and DALLRD work together with industry groups, provincial authorities and researchers to undertake a detailed survey assessing the current size, scope, and geographic extent of the South African wildlife sector. This requires detailed cadastral information which should be entered into a Geographic Information System (GIS). The survey should also assess participation in the different economic activities occurring at contemporary game operations, including game meat production. Obtaining 'buy in' from industry groups will be crucial if accurate results are to be obtained. Wildlife ranching straddles many sectors and is made up of a wide spectrum of stakeholders who hold different interests and viewpoints. There is also a problem of mistrust in the industry which may tend to prefer autonomy and self-regulation.

Despite the many difficulties that persons conducting such a survey may encounter, an up-to-date survey will provide crucial 'baseline data' as a starting point for policy going forward. It will also increase transparency and accountability, helping to address the 'reputational risks' that many in the sector are worried about today.

Recommendation 2: Finalise the draft Game Meat Regulations to the Meat Safety Act and revitalize game meat inspection capacity.

Any expansion of the game meat value chain must anchor on the safety of the meat and related products. At present, a sizeable portion of the game meat entering the domestic market is uninspected. Many (including our interviewees) see this as a key constraint on growth in the sector. The Veterinary Procedural Notices which set the guidelines for exported game meat - and that are currently being followed by some commercial harvesters who also supply the domestic market - might provide a model for updating the domestic draft regulations.

In these times of food scares and concerns about the potential linkage between wild foods and diseases, the industry should not take chances in scaling up game meat production without a proper inspection protocol. As regulations are finalized, it is also important to ensure adequate game meat inspection capacity. This may require the development of new training programs, which could be offered, for example, through the South African Wildlife College.

Quality control and assurance including traceability of all meat products is crucial going forward. With these steps in place, game meat producers will gain the trust of consumers, which is necessary to both the future sustainability and growth of the sector. 
Recommendation 3: Initiate an industry-wide, frank discussion on the issues around transformation in the sector.

While the NBES places a major emphasis on transformation, many feel that government and industry are not moving fast enough as black South Africans largely remain excluded from or highly marginalized within the sector.

There is a pressing need for an industry-wide, frank discussion focusing on the issues around transformation in the sector. We recommend that such discussion be facilitated by an outside agency with expertise in mediating such issues, in order to break the current impasse in which difficult topics around transformation are avoided or reacted to in a defensive manner.

As part of these discussions, it is important to evaluate the outcome of past and ongoing initiatives where results may not be as anticipated (for example, the training of black professional hunters). There is also the need for an in-depth assessment of current trends in the sector, to identify those parts of the value chain that can actually yield meaningful economic benefits, and hence where black ownership should be created or enhanced.

\section{Recommendation 4: Create a dedicated unit to advise new community game farm beneficiaries.}

Community game farms are generally left without sufficient support after the land transfer has taken place, or the protected area designation made. Their autonomy may be compromised by government-imposed conditionalities and they are often unable to accurately assess the various options open to them because they lack the expertise. They clearly require improved post-settlement and post-designation support.

While the government currently favours strategic partnership, co-management and joint venture approaches, it is crucial that such arrangements be fairly structured to ensure that the named beneficiaries actually do benefit. Currently too many communities are being unfairly sidelined within partnership agreements due to their lack of understanding of the implications of these deals.

We recommend that a dedicated unit be created to look at these or other possible arrangements with the aim of helping communities to identify models that will support skills development, employment, and improved livelihoods through successful game-related businesses. This dedicated unit could also be assisted by independent bodies as appropriate (we note for example that Vumelana Advisory Trust has helped to structure several partnership arrangements, including in the game sector). ${ }^{124}$ Alternatively, the unit could unite staff from DALRRD and DEFF with those from the Ministry of Economic Development and/or the Small Enterprises Development Agency.

Recommendation 5: Immediately repeal the recent changes to the Animal Improvement Act and revisit the debate around intensive and selective breeding in 10 years' time.

The expansion of selective breeding and intensive game production in recent years has heightened concerns around the compatibility of the wildlife industry with biodiversity conservation. The recent amendments to the Animal Improvement Act - which some see as geared towards increasing game meat production - have been opposed by conservation scientists and certain industry representatives, some of whom are now pursuing legal action against DALRRD. There is justifiable concern that the legislative 
changes will compromise the integrity of South Africa's wildlife heritage and by extension, the broader wildlife economy. Similarly, the proposed amendment to the Meat Safety Act may deepen this effect.

We recommend that DALRRD immediately repeals the recent amendments to the Animal Improvement Act and facilitates deliberations with stakeholders to chart the way forward for the protection of the genetic integrity of indigenous wildlife. The larger set of issues raised by intensive and selective breeding similarly deserve continued attention, such that we also recommend follow-up to Selier et al.'s expert report on the topic after a period of 10 years. ${ }^{125}$

Recommendation 6: Develop a careful and diversified approach to game meat market development and marketing.

Currently, the industry claims to be pursuing two goals simultaneously: boosting the profile of game meat as a 'premium product'; and addressing food insecurity. These objectives may run at cross purposes since while premium products attract premium prices, game meat must be affordable to low-end consumers if it is to contribute to food security.

Going forward, it may make more sense to focus on developing two distinct markets for game meat products (e.g. by animal, product, meat cut, preparation methods etc.). The Game Meat Industry Strategy that is currently under development should consider the need for diversified campaigns to educate consumers about the range of game meat products and by-products that are available and possible preparation methods. This could be complemented by a similarly diverse set of advertising campaigns encouraging the broader population to integrate game meat into their daily diet.

In addition to providing lower-cost products, food security can be boosted by maximizing the use of by-products and ensuring that game farm employees are paid a fair wage. 


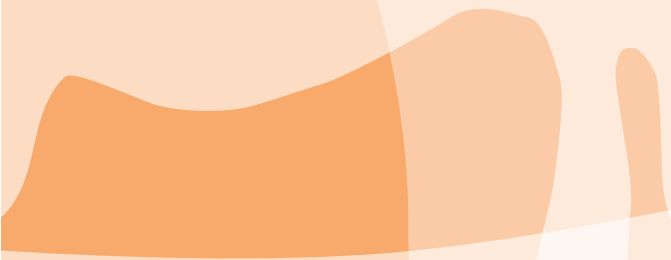

\section{References}

African Indaba. 2017. The colour game is over. African Indaba 15(2).

Baker, A. 2020. South Africa's private game reserves are struggling to survive without tourists: the animals are, too. Available at https://time.com/5888730/south-africa-conservation-private-game-reserve/ [Accessed 19 February 2021].

Bekker, J., L. Hoffman, and P. Jooste. 2011. Essential food safety management points in the supply chain of game meat in South Africa. In P. Paulsen, A. Bauer, M. Vodnansky, R. Winkelmayer and F. Smulder (Eds.) Game Meat Hygiene in Focus: Microbiology, Epidemiology, Risk Analysis and Quality Assurance. Wageningen: Wageningen Academic Publishers. pp. 39-65.

Brooks, S. M. Spierenburg, L. van Brakel, A. Kolk and K. Lukhozi. 2011. Creating a commodified wilderness: Tourism, private game farming, and 'third nature' landscapes in KwaZulu-Natal. Tijdschrift voor Economische en Sociale Geografie 102(3): 260-274.

Brooks, S. and L. Kjelstrup. 2014. An anatomy of dispossession: Post-apartheid land rights and farm dweller relocation in the context of a private game reserve initiative, northern KwaZulu-Natal. Journal of Contemporary African Studies 32(2): 238-257.

Buck, D., C. Getz and J. Guthman. 1997. From farm to table: The organic vegetable commodity chain of Northern California. Sociologia Ruralis 37(1): 3-20. 
Burke, J. 2021. South African game reserves face hard times as COVID stops tourism. Available at: https://www.theguardian.com/world/2021/jan/03/south-african-game-reserves-forced-to-cull-animals-as-covid-halts-tourism [Accessed 16 January 2021].

Carnie, T. 2017. Big drop in prices for rare coloured wildlife. Available at: https://www.news24.com/ witness/news/big-drop-in-prices-for-rare-coloured-wildlife-20171107 [Accessed 13 January 2021].

Carruthers, J. 2008. 'Wilding the farm or farming the wild'? The evolution of scientific game ranching in South Africa from the 1960s to the present. Transactions of the Royal Society of South Africa 63(2): 160-181.

Clements, H., G. Kerley, G. Cummings, A. De Vos and C. Cook. 2019. Privately protected areas provide key opportunities for the regional persistence of large- and medium-sized mammals. Journal of Applied Ecology 56: 537-546.

Cloete, P., P. van der Merwe, and M. Saayman. 2015. Game Ranching Profitability in South Africa. Johannesburg: ABSA \& Barclays.

Cloete, P., E. Janovsky and W. Lemmer. 2019. Game. In: Agricultural Outlook. Autumn Edition 2019. Johannesburg: ABSA. pp. 29-31.

Coalition of African Animal Welfare Organizations (CAAWO). 2019. Where the wild things are. Available at: https://www.caawo.org/2019/12/where-the-wild-things-are [Accessed 13 July 2021].

Convention on Biological Diversity (CBD). 2020. Aichi Biodiversity Targets. Available at: https://www. cbd.int/sp/targets/ [Accessed 30 June 2021].

Cousins, J., J. Sadler, and J. Evans. 2008. Exploring the role of private wildlife ranching as a conservation tool in South Africa: Stakeholder perspectives. Ecology and Society, 13(2): 43 [Online] URL: http:// www.ecologyandsociety.org/vol13/iss2/art43/.

Cousins, J., J. Sadler and J. Evans. 2010. The challenge of regulating private wildlife ranches for conservation in South Africa. Ecology and Society 15(2): 28 [Online] URL: http://www.ecologyandsociety. org/vol15/iss2/art28/.

Creecy, B. 2021. Statement by Minister Creecy: Release of Report of High-Level Panel. DEFF, 2 May.

Davies-Mostert, H. 2014. Overcoming barriers to understanding the biodiversity contribution of private ranchlands. Animal Conservation 17: 399-400.

Department of Environmental Affairs (DEA). 2016a. National Biodiversity Economy Strategy. Available at: https://www.environment.gov.za/sites/default/files/reports/nationalbiodiversityeconomystrategy.pdf [Accessed 10 April 2021].

DEA. 2016b. Biodiversity Lab Fact Pack, Wildlife Economy [Presentation]. March.

DEA. 2016c. Biodiversity and Tourism Lab, Lab Sign-Off [Presentation]. 13 May.

DEA. 2017. Biodiversity Economy Lab, Portfolio Committee Briefing [Presentation]. 29 August.

Department of Environment, Forestry, and Fisheries (DEFF). 2018a. Biodiversity Economy: A Focus on 
the Wildlife Sector, Biodiversity Economy Indaba [Presentation]. 8 March.

DEFF. 2018. Biodiversity Economy (Wildlife) Presentation, Parliament [Presentation]. 27 February.

DEFF. 2020b. Development and Implementation of a Voluntary Market-Based Certification Scheme in the Wildlife Sector [Discussion Document].

DEFF. 2020a. Unlocking the Socio-Economic Potential of South AFrica's Biodiversity Assets through Sustainable Use of Biodiversity, Biodiversity Economy Programme [Presentation]. 19 February.

Derman, B., E. Lahiff and E. Sjaastad. 2010. Strategic questions about strategic partners: Challenges and pitfalls in South Africa's new model of Land Restitution. In: C. Walker, A. Bohlin, R. Hall and T. Kepe (Eds) Land, Memory, Reconstruction, and Justice: Perspectives on Land Claims in South Africa. Athens: Ohio University Press, pp. 306-324.

Dry, G. 2015. An Analysis of Market Potential of Game Meat [Presentation]. Wildlife Farming Conference, 29 August.

Dry, G. 2016. Game Ranching is a Biodiversity Economy Asset Not Part of the Government Conservation Estate [Presentation]. 49th SASAS Congress and 6th International Ratite Symposium, 4 July.

Ducastel, A. and W. Anseeuw. 2017. Agriculture as an asset class: Reshaping the South African farming sector. Agriculture and Human Values 34: 199-209.

Du Toit, J. 2007. Role of the Private Sector in the Wildlife Industry. Pretoria: Wildlife Ranching South Africa.

Endangered Wildlife Trust (EWT). 2020. A word from the CEO. Available at: https://www.ewt.org.za/ wceo-june-2020-a-word-from-the-ceo/ [Accessed 13 July 2021].

Fin24. 2015. Farm to game farm conversions increasing. Available at: https://www.news24.com/fin24/companies/agribusiness/farm-to-game-farm-conversions-increasing-20151203 [Accessed 13 July 2021].

Gallo, J., L. Pasquini, B. Reyers and R. Cowling. 2009. The role of private conservation areas in biodiversity representation and target achievement within the Little Karoo region, South Africa. Biological Conservation 142: 446-454.

Groenewald, Y. 2019. The exotic game market goes bang. Available at: https://mg.co.za/article/201901-11-00-the-exotic-game-market-goes-bang/ [Accessed 9 February 2021]

Guthman, J. 2004. The trouble with 'organic lite' in California: A rejoinder to the 'conventionalisation' debate. Sociologia Ruralis 44(3): 301-316.

Hall, R. 2004. Land and Agrarian Reform in South Africa: A Status Report 2004. Research report no. 20. Institute for Poverty, Land and Agrarian Studies, School of Government. Belleville: University of the Western Cape.

High-Level Panel (HLP) of Experts for the review of Policies, Legislation and Practices on Matters of Elephant, Lion, Leopard and Rhinoceros Management, Breeding, Hunting, Trade and Handling. 2020. High-Level Panel Report - For Submission to the Minister of Environment, Forestry and Fisheries. HLP, 15 December. 
Hoffman, L., M. Swanepoel, and A. Leslie. 2017. African game meat and the safety pertaining to free-ranging wildlife: Example of a wild suid in South Africa. In P. Paulsen, A. Bauer, and F. Smulders, (eds.) Game Meat Hygiene: Food safety and security. Wageningen: Wageningen Academic Publishers.

Hutton, J. and N. Leader-Williams. 2003. Sustainable use and incentive-driven conservation: realigning human and conservation interests. Oryx 37(2): 215-226.

Kamuti, T. 2014. The fractured state in the governance of private game farming: the case of KwaZulu-Natal, South Africa. Journal of Contemporary African Studies 32(2): 190-206.

Kamuti, T. 2015. A critique of the discourse of the green economy approach in the wildlife ranching sector in South Africa. Africa Insight 45(1): 146-168.

Kamuti, T. 2019. "If it pays it stays": The lobby for private wildlife ranching in South Africa. In: Gewald, J.B., M.J. Spierenburg and Wels, H. (eds.). Wildlife Conservation in Southern Africa - Morality and Marginality: Towards Sentient Conservation? Leiden: Brill NV. pp 167-188.

Kitshoff-Botha, A. 2018. Value Chain Perspective: Game Meat Production [Presentation]. 3rd Biodiversity Economy Indaba.

Kitshoff-Botha, A. 2020. COVID-19: Impact Assessment of COVID-19 on the South African Wildlife Ranching Industry. Pretoria: WRSA.

Kuba, J., T. Landete-Castillejos and J. Udała. 2015. Red deer farming: Breeding practice, trends and potential in Poland - A Review. Annals of Animal Science 15(3): 591-599.

Lahiff, E., N. Davis, and T. Manenzhe. 2012. Joint Ventures in Agriculture: Lessons from Land Reform Projects in South Africa. IIED/IFAD/FAO/PLAAS:. London/Rome/Cape Town.

Lindsey, P., S. Romanach and H. Davies-Mostert. 2009. The importance of conservancies for enhancing the value of game ranch land for land mammal conservation in Southern Africa. Journal of Zoology 277: 99-105.

Lion Coalition. 2019. Reclassification of 33 wild mammal species under the Animal Improvement Act. Available at: https://lioncoalition.org/2019/10/30/reclassification-of-33-wild-mammal-species-under-the-animal-improvement-act/ [Accessed 13 July 2021]

McNamara, J., E. Robinson, K. Abernthey, D. Midoko Iponga, H. Sackey, J. Wright, and E. Milner-Gulland. 2021. COVID-19, systemic crisis, and possible implications for the wild meat trade in Sub-Saharan Africa. Environmental and Resource Economics 76: 1045-1066.

Muir-Leresche, K. and R. Nelson. 2000. Private property rights to wildlife: The Southern African experiment. Mimeo, Harare and Maryland: University of Zimbabwe and University of Maryland.

National Agricultural Marketing Commission (NAMC). 2006. Report on the Investigation to Identify Problems for Sustainable Growth and Development in South African Wildlife Ranching. NAMC: Pretoria.

National Council of Societies for the Prevention of Cruelty to Animals (NSPCA). 2019a. NSPCA lays cruelty charges against game farm, Hawks involved in investigation. Available at: https://nspca.co.za/ news/nspca-lays-cruelty-charges-against-game-farm-hawks-involved-in-investigation/ [Accessed 13 July 2021]. 
NSPCA. 2019b. High court rules in favour of lions and NSPCA. 6 August. Available at: https://nspca. co.za/news/high-court-rules-in-favour-of-lions-and-nspca/ [Accessed 16 June 2016].

Ngubane, M. and S. Brooks. 2013. Land beneficiaries as game farmers: Conservation, land reform and the invention of the 'community game farm' in KwaZulu-Natal. Journal of Contemporary African Studies 31(3): 399-420.

Oberem, P. 2016. If it pays, it stays. Wildlife Ranching (5): 230-234.

Peros, C., R. Dasgupta, P. Kumar and B. Johnson. 2021. Bushmeat, wet markets, and the risks of pandemics: Exploring the nexus through systematic review of scientific disclosures. Environmental Science and Policy 124: 1-11.

Phillips, L. 2019. Bringing more South African game meat to dinner tables. Available at: https://www. farmersweekly.co.za/animals/game-and-wildlife/bringing-more-south-african-game-meat-to-dinner-tables/ [Accessed 4 November 2020].

Phillips, L. 2020. Game reserve turns to meat sales amid COVID-19 tourism ban. Available at: https:// www.farmersweekly.co.za/agri-news/south-africa/game-reserve-turns-to-meat-sales-amid-covid-19tourism-ban/ [Accessed 7 July 2021].

Pirie, T., R. Thomas and M. Fellowes. 2017. Increasing game prices may alter farmers' behaviours towards leopards (Panthera pardus) and other carnivores in South Africa. PeerJ. 5: e3369. [Online] URL: https://peerj.com/articles/3369/.

Pooley, S., M. Barua, W. Beinart, A. Dickman, G. Holmes, J. Lorimer, A. Loveridge, D. Macdonald, G. Marvin, S. Redpath, C. Sillero-Zubiri, A. Zimmermann and E. Milner-Gulland. 2017. An interdisciplinary review of current and future approaches to improving human-predator relations. Conservation Biology 31(3), 513-523.

Property24. 2015. South Africa's game farm industry is booming. Available at: https://www.property24.com/articles/south-africas-game-farm-industry-is-booming/23254\#: :text=Real\%20estate\%20 companies\%20involved\%20in,over\%20the\%20last\%20ten\%20years.\&text=Commins\%20says\%20 the\%20trend\%20to,battling\%20to\%20make\%20ends\%20meet [Accessed 13 July 2021].

Rubino, M. 2000. Biodiversity finance. International Affairs 76(2): 223-240.

Saayman, M., P. van der Merwe, and A. Saayman. 2018. The economic impact of trophy hunting in the South African wildlife industry. Global Ecology and Conservation 16: e00510. [Online] URL: https://doi. org/10.1016/j.gecco.2018.e00510.

Saayman, M. and E. Slabbert. 2018. Game meat potential: The unrealised potential of game meat in South Africa. Wildlife Ranching, 3: 112-117.

Selier, J., L. Nel., I. Rushworth., J. Kruger, B. Coverdale, C. Mulqueeny and A. Blackmore. 2018. An assessment of the potential risk of the practice of intensive and selective breeding of game to biodiversity and the biodiversity economy in South Africa. Available at: https://portals.iucn.org/library/sites/ library/files/resrecrepattach/Sci\%20Auth\%20Selective\%20Intensive\%20breeding\%20report\%20\%20 Final\%20Jul2018.pdf [Accessed 4 June 2021]. 
Serrano, M., A. Maggiolino, T. Landete-Castillejos, M. Pateiro, J. Pérez Barbería, Y. Fierro, R. Domínguez, L. Gallego, A. García, P. De Palo, and J. Lorenzo. 2020. Quality of main types of hunted red deer meat obtained in Spain compared to farmed venison from New Zealand. Scientific Reports 10 (12157): $1-9$.

Shumba, T., A. De Vos, R. Biggs, K. Esler, J. Ament, and H. Clements. 2020. Effectiveness of private land conservation areas in maintaining natural land cover and biodiversity intactness. Global Ecology and Conservation 22: e00935. [Online] URL: https://doi.org/10.1016/i.gecco.2020.e00935.

Slabbert, A. 2013. Why does Johann Rupert invest in buffalo? Available at: https://www.moneyweb. co.za/archive/can-game-farming-outperform-the-jse/ [Accessed 22 April 2021].

Smith, D. 2014. Cyril Ramaphosa in line of fire over profits from game farm. Available at: https://www. theguardian.com/world/2014/sep/08/cyril-ramaphosa-criticised-profits-game-south-africa [Accessed 03 February 2021].

Snijders, D. 2012. Wild property and its boundaries: On wildlife policy and rural consequences in South Africa. Journal of Peasant Studies 39(2): 503-520.

Snijders, D. 2015. Shifting Species in South Africa: Wildlife Policy, Rural Consequences [PhD Dissertation]. Amsterdam: VU University.

Somers, M. M. Walters, J. Measey, W. Strauss, A. Turner, J. Venter, L. Nel, G. Kerley, W. Taylor, and Y. Moodley. 2020. The implications of the reclassification of South African wildlife species as farm animals. South African Journal of Science 116(1/2): Article 7724.

Sommerville, M. 2019. Agrarian Repair: Agriculture, Race, and Accumulation in Contemporary Canada and South Africa [PhD Dissertation]. Vancouver: Department of Geography, University of British Columbia.

South Africa Press Association (SAPA). 2012. Ramaphosa apologises for buffalo bid. Available at: https://www.timeslive.co.za/news/south-africa/2012-09-20-ramaphosa-apologises-for-buffalo-bid/ [Accessed 14 March 2021].

Spierenburg, M., and S. Brooks. 2014. Private game farming and its social consequences in post-apartheid South Africa: Contestations over wildlife, property and agrarian futures. Journal of Contemporary African Studies 32(2): 151-172.

StatsSA. 2019. Tourism Satellite Account for South Africa, final 2016 and provisional 2017 and 2018. Report number: 04-05-07. Johannesburg: Statistics South Africa.

Taylor, W., P. Lindsey, and H. Davies-Mostert. 2016. An Assessment of the Economic, Social and Conservation Value of the Wildlife Ranching Industry and its Potential to Support the Green Economy in South Africa. Johannesburg: The Endangered Wildlife Trust.

Taylor, W., P. Lindsey, S. Nicholson, C. Relton, and H. Davies-Mostert. 2020. Jobs, game meats and profits: The benefits of wildlife ranching on marginal lands in South Africa. Biological Conservation 245: 108561. [Online] URL: https://doi.org/10.1016/j.biocon.2020.108561. 
United Nations Development Program (UNDP). 2018. Terms of Reference: Biodiversity Finance Initiative (BIOFIN). A literature review and feasibility study on the development of a market-based certification scheme in the wildlife sector of South Africa. Available at: https://procurement-notices.undp.org/view file.cfm?doc id=141099. [Accessed 12 June 2021].

Uys, G. 2016. Game exports after FMD. Available at: https://www.farmersweekly.co.za/agri-business/ agribusinesses/game-exports-after-fmd/ [Accessed 13 July 2021].

van der Merwe, P. 2018. Counting the contribution of hunting to South Africa's economy. Available at: https://theconversation.com/counting-the-contribution-of-hunting-to-south-africas-economy-106715 [Accessed 1 February 2021].

van der Merwe, M., P. Jooste and L. Hoffman. 2011. Application of European standards for health and quality control of game meat on game ranches in South Africa. South African Journal of Veterinary Association $82(3): 170-5$.

van der Merwe, P., M. Saayman and W. Krugell. 2004. Factors that determine the price of game. Koedoe: Protected Area Science and Management 47: 105-113.

Wertheim, M. (no date). What Are the Health Benefits of Wild Game? Available at: https://www.livestrong.com/article/349448-what-are-the-health-benefits-of-wild-game/ [Accessed 2 June 2021].

Wildlife Ranching South Africa (WRSA). 2018. Submission on Expropriation Without Compensation. 15 June. Available at: https://www.wrsa.co.za/submission-on-land-expropriation-without-compensation/ [Accessed 16 June 2021].

Wilshusen, P., S. Brechin, C. Fortwangler and P. West. 2002. Reinventing a square wheel: Critique of a resurgent 'protection paradigm' in international biodiversity. Society and Natural Resources 15: 17-40.

Zerbst, F. 2015. Game meat leaps globally. Wildlife Ranching. Available at:

https://www.wrsa.co.za/game-meat-leaps-globally/ [Accessed 16 June 2021].

Zerbst, F. 2017. Game meat: Steps to market. Wildlife Ranching (6): 87-91. 
